Review

\title{
Synthetic Procedures Leading towards Aminobisphosphonates
}

\author{
Ewa Chmielewska * and Paweł Kafarski
}

Department of Bioorganic Chemistry, Faculty of Chemistry, Wrocław University of Science and Technology, Wrocław 50-370, Poland; pawel.kafarski@pwr.edu.pl

* Correspondence: ewa.chmielewska@pwr.edu.pl; Tel.: +48-71-320-29-77; Fax: +48-71-320-24-27

Academic Editor: György Keglevich

Received: 30 September 2016; Accepted: 2 November 2016; Published: 4 November 2016

\begin{abstract}
Growing interest in the biological activity of aminobisphosphonates has stimulated the development of methods for their synthesis. Although several general procedures were previously elaborated to reach this goal, aminobisphosphonate chemistry is still developing quite substantially. Thus, innovative modifications of the existing commonly used reactions, as well as development of new procedures, are presented in this review, concentrating on recent achievements. Additionally, selected examples of aminobisphosphonate derivatization illustrate their usefulness for obtaining new diagnostic and therapeutic agents.
\end{abstract}

Keywords: bisphosphonates; bisphosphonylation procedures; Vilsmayer-Haack-like reactions; functionalization of aminoalkylbisphosphonates

\section{Introduction}

Bisphosphonates are a class of compounds that are currently receiving significant attention. Over 50 new papers are seen each week when searching the literature with the keyword "bisphosphonate" via Web of Science. More than 17,000 various bisphosphonate structures have been synthesized and described in the literature [1]. Most papers concern their important subclass, namely aminobisphosphonates. This strong interest results from these compounds acting as strong inhibitors of bone resorption, with several representatives of this class already commercialized as drugs of choice for the treatment of osteoporosis, skeletal complications of malignancy, Paget's disease, multiple myeloma, hypercalcemia and fibrous dysplasia [2-7] Consequently, most of the papers are devoted to various clinical aspects of the anti-resorptive effects that bisphosphonates exert towards bone tissues; however, there is also a growing interest in their applications as anticancer and antibacterial agents [5-7]. Additionally, aminobisphosphonic acids have found important industrial applications, largely as inhibitors of scale formation and as corrosion inhibitors, actions which result from their ability to complex metal ions [8-10].

Thus, simple and effective procedures for their synthesis are becoming increasingly important. However, only a few general reactions leading to these compounds have been described to date and are only partially reviewed in the literature [11,12]. Novel reports are mostly concentrated on modifications and improvement of these procedures, and there are only a few papers aiming at new reactions, which results from the commonly applied procedures being simple, economical and effective.

In this paper, we comprehensively review the recent studies (supplemented by older papers if necessary) on reactions applied to synthesize the most important class of bisphosphonatesaminobisphosphonates-and discuss their scope and limitations. 


\section{Overview of Synthetic Procedures}

There are contradictory reports of the origin of bisphosphonates [13]. Most likely, the first one was obtained in the 19th century by Nikolay Menschutkin and/or Theodor Saltzer as an impurity in reactions designed to obtain different compounds. It was further identified by Hans von Baeyer and Wilhelm Heideprim as 1-hydroxyethanebisphosphonic acid.

There are only a few general methods for the synthesis of aminobisphosphonates. However, there are many individual procedures described for their preparation [11,12]. In this review, the following general reactions are presented: (i) starting from carboxylic acids and (ii) their amides; (iii) reactions using nitriles and (iv) isonitriles as substrates; (v) syntheses based on addition of phosphites to oxophosphonates; (vi) three-component condensation of amines, trialkyl orthoformates and dialkyl phosphites; (vii) addition of amines to vinylidenebisphosphonates; and (viii) functionalization of simple bisphosphonates treated as building blocks for the preparation of more complex structures. Additionally, some specific and non-conventional procedures that have been elucidated will be presented in this review.

\subsection{Synthesis from Carboxylic Acids}

1-Hydroxyethylidene-1,1-bisphosphonic acids are perhaps the oldest group of bisphosphonates. They are standardly prepared by a large-scale, one-step reaction of carboxylic acids with phosphorus trichloride and phosphorous or phosphoric acids, followed by hydrolysis with water; the procedure was optimized by Kieczykowski et al. [14]. The reaction is carried out in selected solvents (phenylsulphonic acid, various phenols, chlorobenzene, diphenyl ether or ionic liquids) with sulfone and methanesulphonic acid being preferred choices [11,15-20]. Despite many theories [19,21-23], the exact mechanism of this reaction is not fully understood; however, the formation of acid chloride as a first intermediate has been undoubtedly demonstrated (Scheme 1). This intermediate may react with methanesulphonic acid (when used as a solvent), and the formed mixed anhydride is also considered a potential intermediate for the next step [24], which is an Arbuzov-like reaction of phosphorus acid or one of its several derivatives (including anhydrides of variable structure [17]) formed during the reaction. The formed derivative of ketophosphonate is a substrate for the addition reaction of trivalent $\mathrm{P}-\mathrm{OH}$ species, and bisphosphonate is obtained (Scheme 1). It has also been documented that the use of phosphorous acid could be omitted if water was added to the reaction medium, and thus this compound was formed in situ.

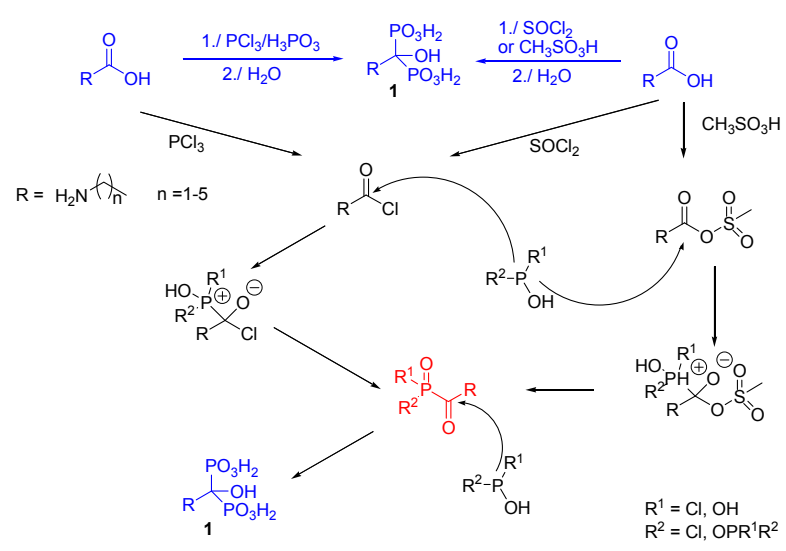

Scheme 1. Presumable mechanism of the synthesis of 1-hydroxy-1,1-bisphosphonic acids.

This reaction was commonly used for the preparation of a wide variety of anti-osteoporotic bisphosphonic acids containing free amino groups (so called dronic acids, compound $\mathbf{1}$ ). In this case, free unblocked amino acids are used as substrates, and the final neutralization of reaction mixtures to a $\mathrm{pH}$ of approximately 4 causes precipitation of the desired products, which are formed in satisfactory 
yields and are of good purity [16,23-26]. Because of its technological importance, this reaction is still quite intensively studied and optimized; however, most of the studies are done in industrial laboratories, and their results are mostly disseminated as patents. Consequently, it is difficult, if not impossible, to determine which conditions are optimal for the synthesis of individual drugs. It is important because, as in the case of any multicomponent reaction, a synthetic course is strongly dependent on applied conditions and molar ratios of reagents. For example, one of the patents reports that the omission of phosphorus chloride in the reaction of 4-aminobutyric acid as the substrate in methanesulphonic acid provides mixtures of anhydrides as final products (compounds 2 and 3, Scheme 2) [11]. This corresponds well to the known tendency of phosphonic acids to cyclize.
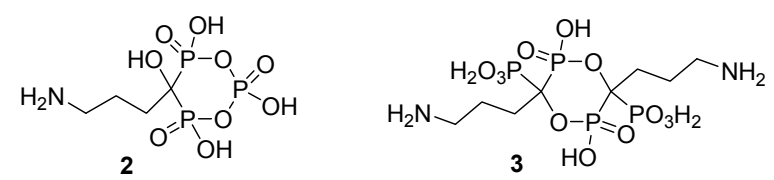

Scheme 2. Cyclic products of the reaction between carboxylic acids and phosphorous acid in methanesulphonic acid.

Among modifications of this procedure are (i) replacement of phosphorus trichloride with thionyl chloride to generate acid chloride in the first reaction step [11]; (ii) replacement of acid by its chloride or anhydride [11] or (iii) t-butyl ester [27]; (iv) blocking the amino moiety in the case of $\alpha$-amino acids [28]; and (v) application of microwave-assisted procedures [29].

\subsection{Synthesis from Amides}

Although studies on the biological activity of 1-amino-1,1-bisphosphonic acids are scarce, a significant number of procedures for their preparation have been described. They have recently been reviewed by Romanenko and Kukhar [12]. Amides, being highly stable and easily available compounds, are substrates of choice, and the most commonly applied procedures are simple modifications of those elaborated for carboxylic acids. The most straightforward are reactions of $\mathrm{N}$-acylamines and $\mathrm{N}$-formylamines with phosphorus trichloride and phosphorous acid [30-32], phosphorus tribromide [33], or triphosgene [34], which provide a wide structural variety of 1-amino-1,1-bisphosphonic acids (compound 4, Scheme 3). They are based on modification of the first procedure elaborated by Plöger et al. with formamide as a substrate [35].

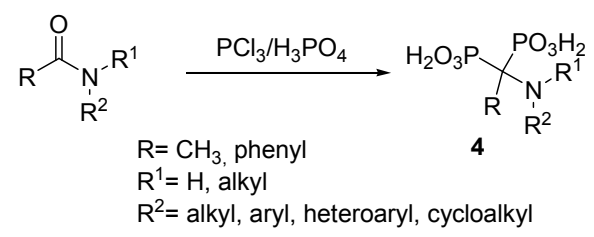

Scheme 3. Bisphosphonylation of amides.

The exact reaction mechanism in this case is also not fully known; however, a VilsmayerHaack-like route via iminium ion is postulated here (Scheme 4).

Another possibility is using trialkyl or trimethylsilyl phosphites in reactions prompted by phosphoryl chloride [36-39], trifluoromethanesulphonic anhydride $\left(\mathrm{Tf}_{2} \mathrm{O}\right)$ [40], zinc chloride [41] or trimethylsilyl trifluoromethanesulfonate $[42,43]$. Unfortunately, primary amides are not suitable substrates for this reaction [38]. The use of triethyl phosphite and phosphoryl chloride appeared to be especially useful when lactams were used as substrates, resulting in high yields of aminomethylenegem-bisphosphonates (Scheme 5) [36-39]. They were readily hydrolyzed, yielding corresponding bisphosphonic acids (representative example compound 5). On the other hand, this reaction is not suitable for the conversion of benzoannulated lactams, and mixtures of the desired bisphosphonates and 
monophosphonates of variable structures were obtained (compounds $\mathbf{6 , 7 , 8}$ and $\mathbf{9}$, Scheme 5). In fact, monophosphonates are usually major products, and the reaction course is dependent on the size of the substrate aliphatic ring [44]. Additionally, these bisphosphonates and monophosphonates appeared to be unstable upon acid hydrolysis and upon storage, and undergo degradation with cleavage of the carbon-to-phosphorus bond (for example compound 10, Scheme 5). Thus, corresponding acids have not yet been obtained.

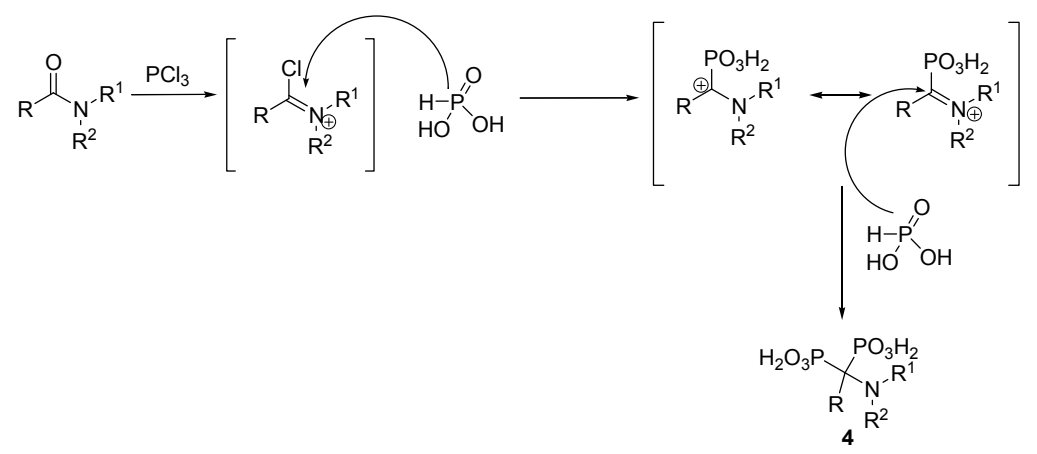

Scheme 4. Bisphosphonylation of amides and the presumable mechanism of this reaction.
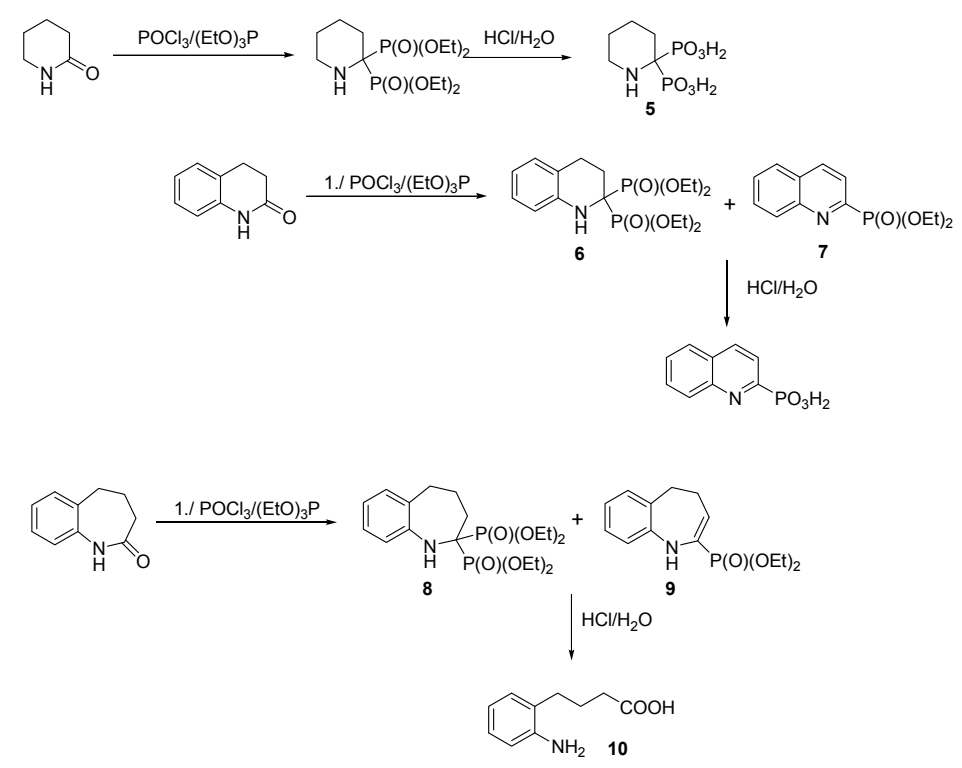

Scheme 5. Representative reactions of lactams with triethyl phosphite prompted by phosphoryl chloride.

The formation of a Vilsmayer-Haack-like intermediate is also proposed in this case with the further addition of a nucleophilic phosphorus reagent. This assumption is additionally supported by studies on the use of structurally variable imine salts as substrates for synthesis of compounds $\mathbf{1 1}$ (Scheme 6) [41-45].

The reaction of dibutoxyphosphine or bis(trimethylsiloxy)phosphine with dimethylformamides in the presence of trimethylsilyl trifluoromethanesulfonate affords the corresponding aminomethylenebisphosphonites 12 in high yields (Scheme 7) [41-43]. Similar products were obtained by reacting diethyl pivaloylphosphonite with dialkylformamides in the presence of excess ethanol and catalytic amounts of zinc chloride (Scheme 7). Pivaloylphosphonite decomposes in these reaction conditions, yielding diethoxyphosphine, which is the real substrate of the reaction [41].

$\mathrm{N}$-Octylpyrrolidinone treated with LDA, followed by the addition of diethyl phosphorochloridite and oxidation of the reaction mixture with $30 \%$ hydrogen peroxide resulted in bisphosphonylated lactam 13 with excellent yield (Scheme 8). This reaction was then applied for the synthesis 
of $\mathrm{N}$-geranylated lactams $\mathbf{1 4}$ and $\mathbf{1 5}$ and linear amides, potential inhibitors of farnesyl:protein transferase [46]. In the case of cyclic imides, in which two equivalent positions for enolate formation are present on the imide rings, and thus two carbon atoms may be phosphonylated, the structure of the product was dependent on the mode of reaction. If phosphonylation was carried out in one step, two carbon atoms were phosphonylated and vicinal bisphosphonate was obtained. Step-by-step reaction resulted in the predomination of the phosphonylation of one carbon atom, and the desired gem-bisphophonate was the major product.

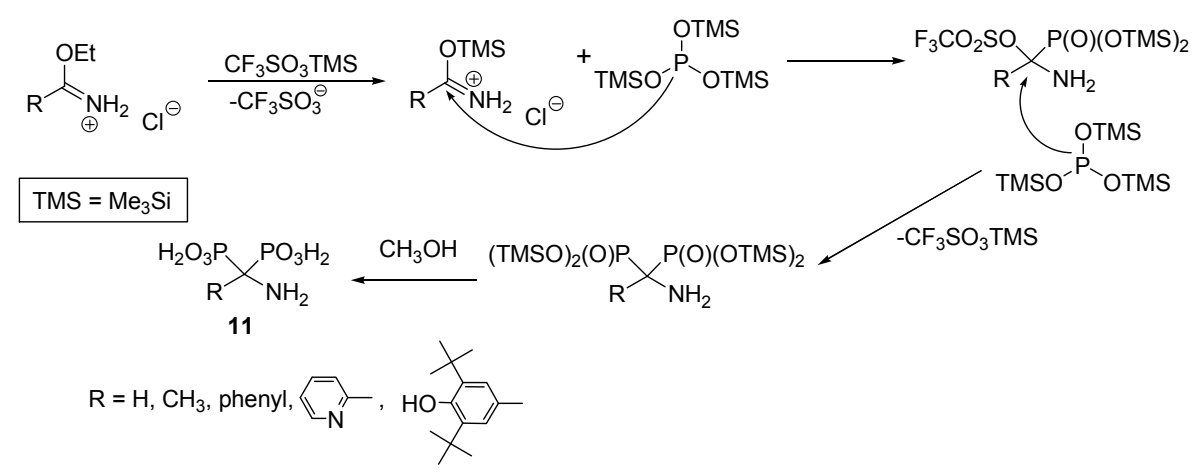

Scheme 6. Imine salts as substrates for preparation of bisphosphonic acids.

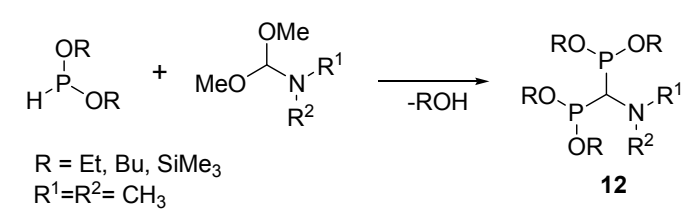

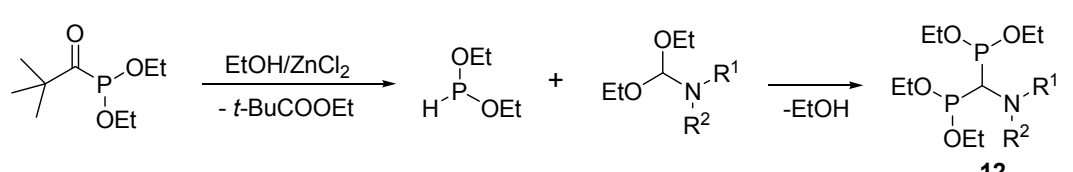

$$
\begin{aligned}
& \mathrm{R}^{1}=\mathrm{R}^{2}=\mathrm{CH}_{3}, n \text {-propyl, } \\
& \mathrm{R}^{1}, \mathrm{R}^{2}=-\left(\mathrm{CH}_{2}\right)_{5^{-}},-\mathrm{CH}_{2} \mathrm{CH}_{2} \mathrm{OCH}_{2} \mathrm{CH}_{2}- \\
& 12
\end{aligned}
$$

Scheme 7. Reaction of diethoxyphosphine with the acetal of dimethylformamide.
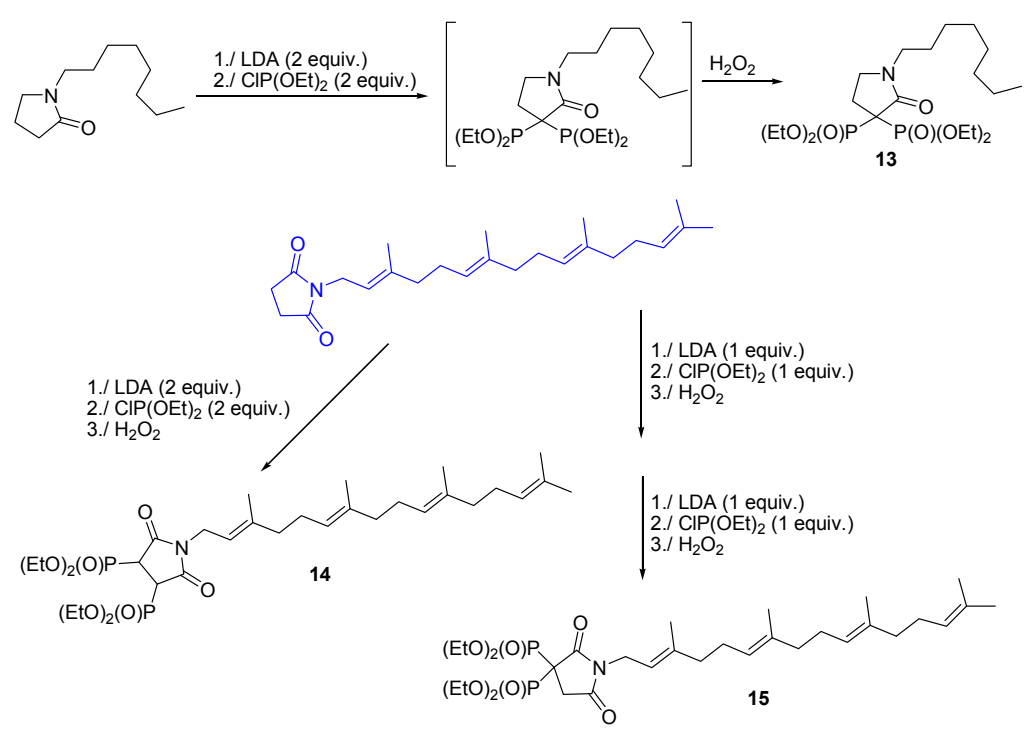

Scheme 8. Synthesis of bisphosphonate lactams. 


\subsection{Synthesis from Nitriles}

1-Aminoalkylidene-1,1-bisphosphonic acids could also be prepared from nitriles by applying the same procedures as in syntheses starting from amides. Despite being readily available substrates, there is limited literature on their use for that purpose. The most popular route is the reaction of nitriles with phosphorous acid, in some cases prompted by phosphorus trichloride and phenylsulphonic or methylsulphonic acids $[12,31,47,48]$. The conditions of this reaction are sufficiently delicate to use peptidyl nitriles as substrates, which was demonstrated using cyanoethyl derivatives of dipeptides (for example, peptide 16, Scheme 9) [49].

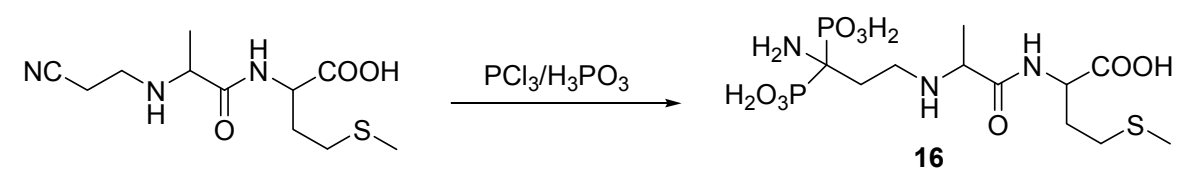

Scheme 9. Representative example of the synthesis of peptidylbisphosphonates from nitriles.

Recently, elegant, mild, and atom economical double phosphonylation of nitriles in the presence of titanocene has been described. This procedure used induced phosphorus-centered radicals mediated by titanocene dichloride $\left(\mathrm{Cp}_{2} \mathrm{TiCl}_{2}\right)$ (Scheme 10) and provided a wide structural variety of aminobisphosphonates 17 [50]. This is a double radical transfer reaction initiated by the reaction of titanocene with zinc dust and the transfer of the obtained radical to epoxypropane by cleavage of its oxirane ring, followed by transfer of this radical to diethyl phosphite, which in turn reacts with nitrile (Scheme 10). The reaction carried out without epoxide, under microwave stimulation, also results in the desired bisphosphonates, although it is accompanied by formation of many side products.

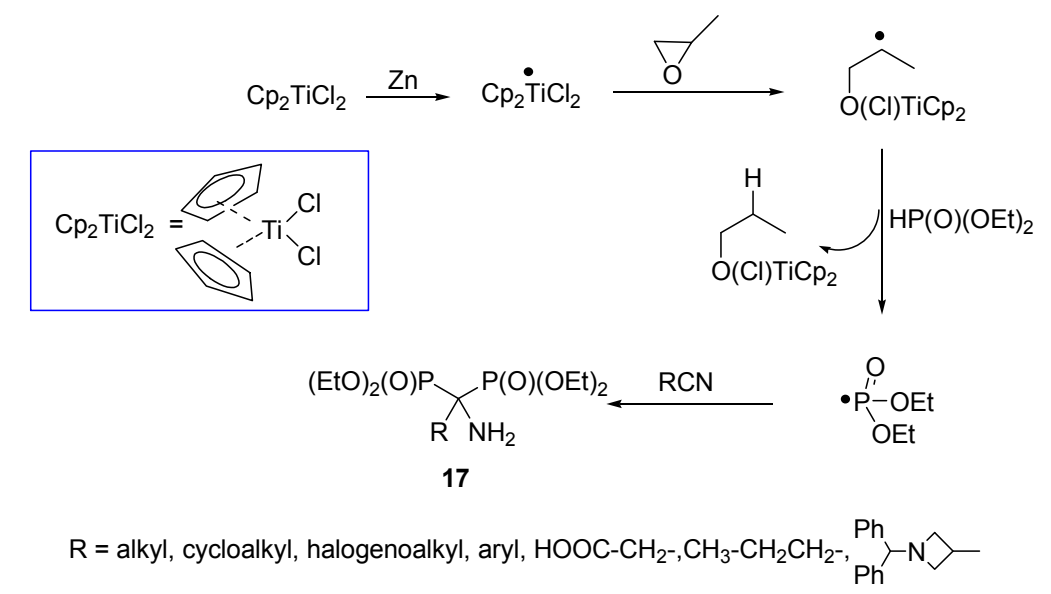

Scheme 10. Radical procedure for the synthesis of bisphosphonates from nitriles.

\subsection{Synthesis from Isonitriles}

Isonitriles, which are quite common substrates, especially in multicomponent reactions [51], have been seldom used for the preparation of aminobisphosphonates 18. Their reactions with $H$-phosphine oxides carried out in the presence of typical palladium catalysts $\left(\mathrm{Pd}_{2} \mathrm{dba}_{3}\right)$ afforded the product 19 of monophosphonylation, whereas the use of various rhodium catalysts afforded products of diphosphonylation (Scheme 11) [52].

Far simpler is the addition of diethyl phosphite to isonitriles. This reaction is carried out with an excess of hydrogen chloride in aprotic solvents. Under these conditions, nitrile is converted to an onium salt, and after addition of the first phosphite molecule, iminium salt is formed, a substrate for the addition of a second phosphite molecule (Scheme 12) [53]. Using this procedure, two distinct libraries of bisphosphonates 20 and 21 have been prepared [54-56]. 


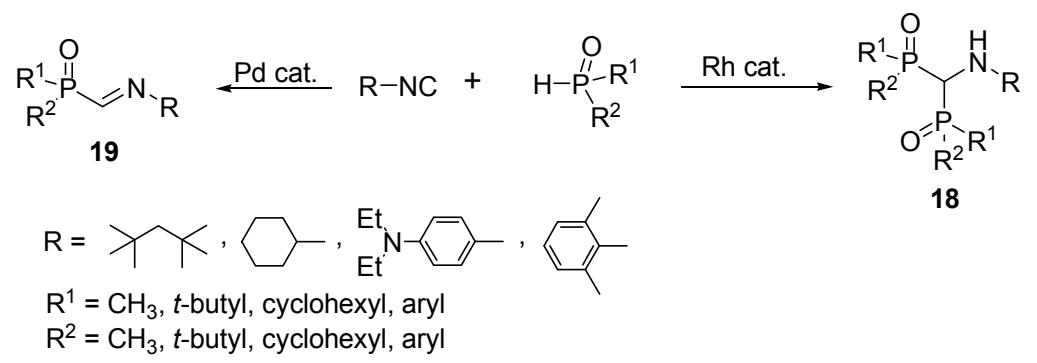

Scheme 11. Addition of $H$-phosphine oxides to isonitriles catalyzed by metallocatalysts.

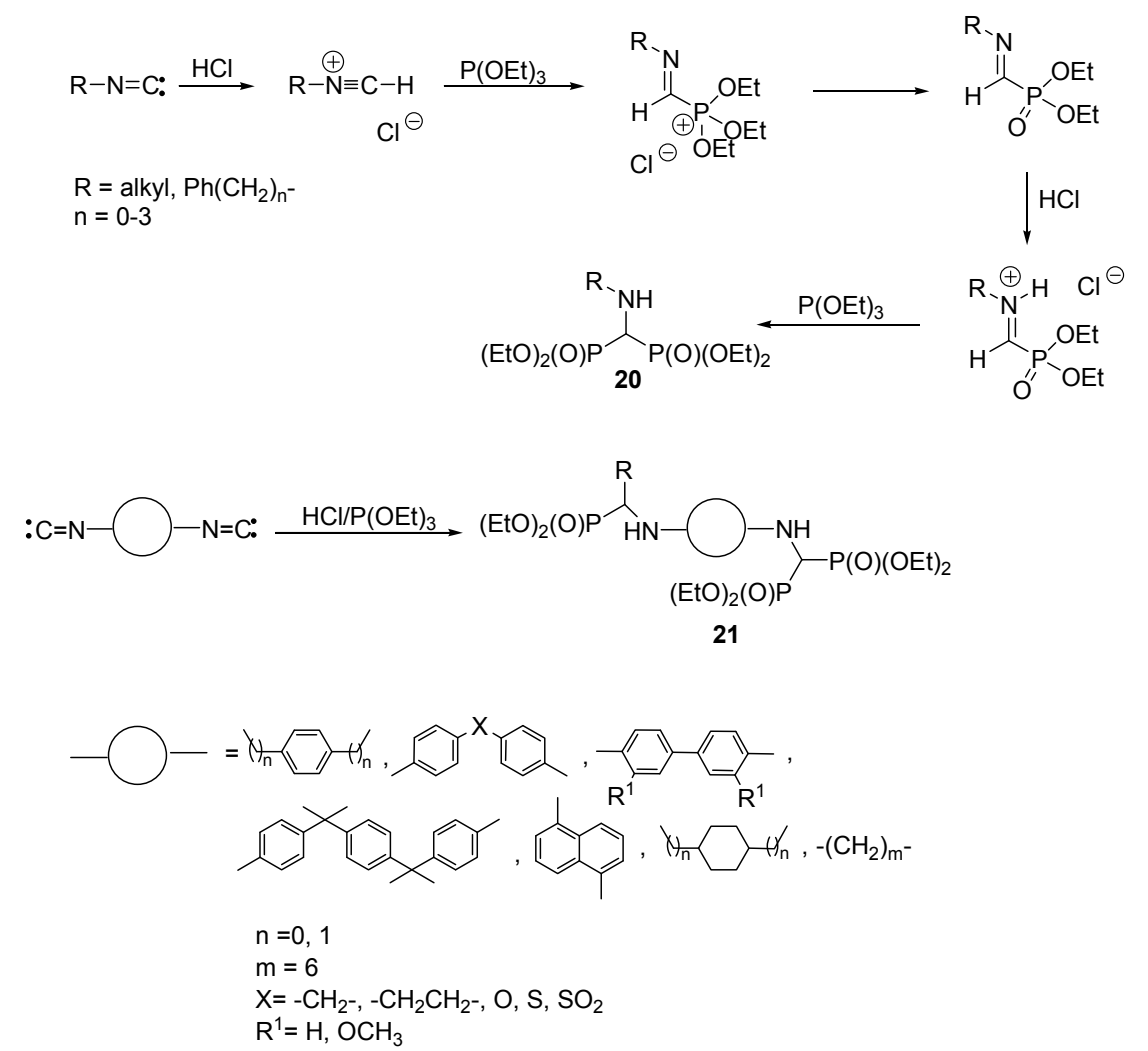

Scheme 12. Addition of phosphites to isonitriles.

\subsection{Synthesis via Ketophosphonates}

Presumably, the addition of phosphites to ketophosphonates was the first procedure for preparation of dialkyl 1-hydroxy-1,1-bisphosphonates [16,19,57]. Starting ketophosphonates are obtained by the Arbuzov reaction of acyl chlorides with trialkyl phosphites and used as substrates in the next step, namely, the addition of dialkyl phosphite to carbonyl double bonds (a representative example for preparation of tetramethyl pamidronate 22 is shown in Scheme 13). Since ketophosphonates are unstable species [58], the desired bisphosphonates are usually obtained via one-pot procedures applying mixtures of trialkyl- and dialkylphosphonates at elevated temperature [59]. Additionally, in situ generation of dialkyl- from trialkyl phosphites is possible by the addition of a protic solvent to the reaction mixture. A useful modification of this procedure is the application of tris(trimethylsilyl) phosphite, followed by the easy removal of ester groups by methanolysis $[23,60,61]$. This was used to prepare a wide variety of 1-hydroxy-1,1-bisphosphonates containing amino groups [19,23,61-63]. Additionally, the use of bis((trimethylsilyl)oxy)phosphine generated from ammonium hypophosphite was applied to prepare hydroxybisphosphinic acids (also presented in Scheme 13) [64]. Another modification was the use of acyl phosphonamidates readily prepared from phosphoramidite type 
reagents and a range of acid chlorides, followed by reaction with trimethyl phosphite in the presence of pyridinium perchlorate [65].

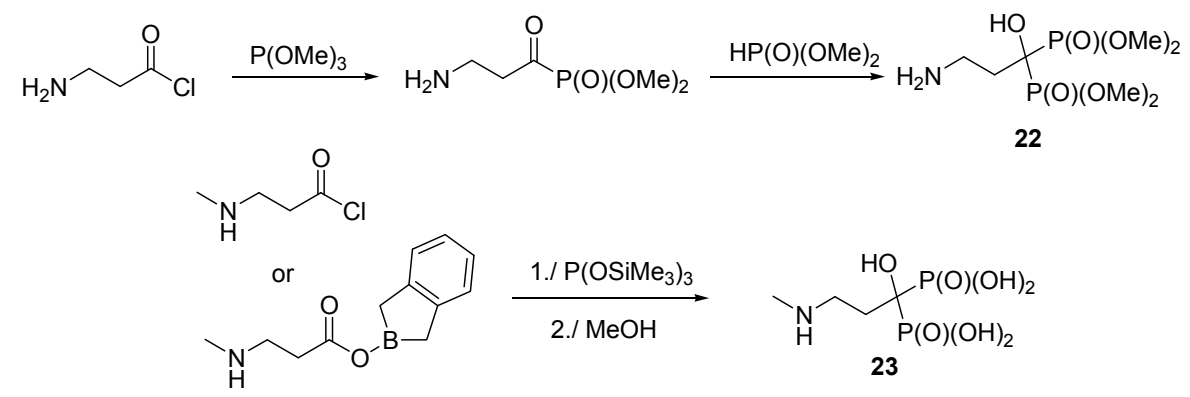

Scheme 13. Representative syntheses via ketophosphonates.

Recently, a one-pot synthesis was described reacting carboxylic acids with catecholborane, followed by the treatment of the formed acyloxy-benzodioxaborolane with tris(trimethylsilyl)phosphite (Scheme 13) [66]. The efficiency of that simple methodology was proved by the syntheses of alendronate and $N$-methyl pamidronate (compound 23) without additional steps for the protection/deprotection of their amine functions.

\subsection{Three-Component Condensation of Amines with Triethyl Orthoformate and Diethylphosphite}

Simple three-component condensation of stoichiometric ratios of amines, diethyl phosphite and triethyl orthoformate, first reported in patent literature by Suzuki [67] and further extended by Maier [68], is perhaps the most common procedure for the preparation of a wide variety of aminomethylenebisphosphonic acids (Scheme 14). Since this reaction usually gives a complex mixture of products [56] that are difficult to separate, the resulting esters are not isolated but rather, the crude reaction mixtures are hydrolyzed, yielding bisphosphonic acids that are isolated after the hydrolytic step. Some modifications of this classic procedure have also been reported. They include the use of a solvent-free, microwave-assisted reaction [69-71] and reactions catalyzed by titanium dioxide [72] and by crown ethers (increasing the selectivity of the process by $10 \%-20 \%$ ) [73]. Additionally, a reaction carried out in a micellar environment was described [74].

$$
\begin{aligned}
& \mathrm{R}-\mathrm{NH}_{2}+\mathrm{H}-\mathrm{C}(\mathrm{OEt})_{3}+\mathrm{HP}(\mathrm{O})(\mathrm{OEt})_{2} \frac{1 . / \triangle}{2 . / \mathrm{HCl} / \mathrm{H}_{2} \mathrm{O}} \\
& \mathrm{R}=\text { over } 300 \text { structurally variable substituents }
\end{aligned}
$$

Scheme 14. Condensation of amines with triethyl orthoformate and diethyl phosphite.

The three-component reaction was applied to synthesize a large series of physiologically active compounds, in some cases of very complex chemical structures, including bone antiresorptive drug candidates [75-82]; bone imaging [83,84], antiprotozoal [85-88], antibacterial [72,89-92], anti-HIV [93] and anti-inflammatory [94] agents; herbicides [95-97]; and complex ones for various metals [10,98].

In some cases, this reaction appears to be quite capricious and affords unexpected side-products along with the expected aminomethylenebisphosphonates (see representative examples in Scheme 15), the compositions of which are dependent on the applied conditions (molar ratio of substrates, temperature and reaction time). Most often, alkylation (for example, compounds 24 and 25) or formylation (compound 26) of amine moieties is observed [71,99], while in selected cases the formation of aminomethylenebisphosphonic acid (compound 27) is observed. Because this compound was previously prepared by acid hydrolysis of $N$-benzhydrylaminomethylenebisphosphonic acid $[83,100]$, it may be that it is formed upon hydrolysis of $N$-aryl derivatives. 


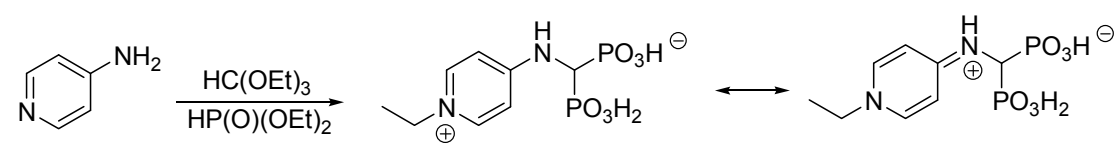

24

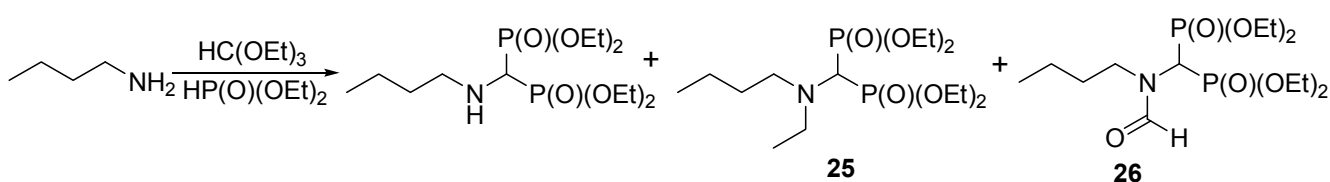

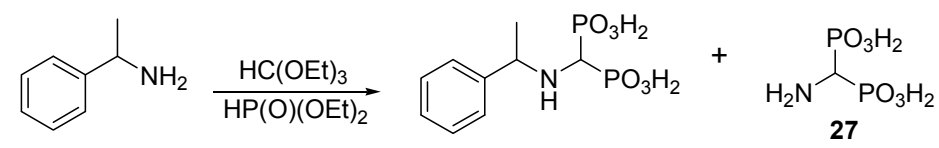

Scheme 15. Representative side products of the three-component procedure for the synthesis of aminomethylenebisphosphonic acids.

The mechanism of this useful reaction had been thoroughly studied by using ${ }^{31} \mathrm{P}-\mathrm{NMR}$ and by isolation of all intermediates [71,72,99] and identifying interrelations between them (Scheme 16) [99]. The mechanism appeared to be quite complex because the intermediates exist in thermodynamic equilibrium. Thus, its course is strongly dependent on the properties of the used amine and applied reaction conditions.

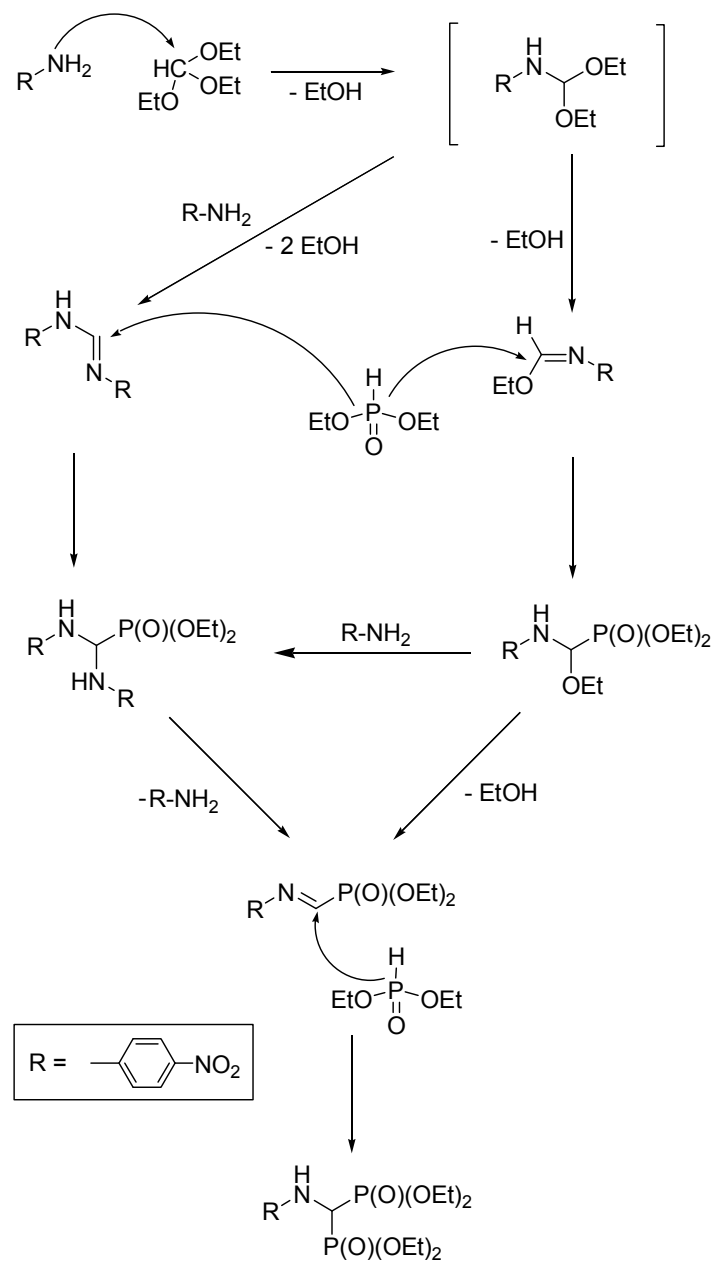

Scheme 16. Mechanism of the three-component reaction of amines with orthoformates and phosphites. 
Modification of this procedure and the use of ethyl diethoxymethyl- $H$-phosphinate instead of diethyl phosphite allowed obtaining structurally variable bisphosphinates 28 (Scheme 17) [101]. Better results were obtained if the reaction was carried out under nitrogen (air oxidizes substrates and products). Notably, aromatic amines provided the desired bisphosphinates in high yields $(78 \%-92 \%)$, whereas the reaction yields when using cyclic and aliphatic derivatives were lower. Interestingly, of many methods for the synthesis of corresponding acids $\mathbf{2 9}$, acidolysis of the obtained esters $\mathbf{2 8}$ appeared to be optimal. The use of other conditions, including mild transesterification with trimethylsilyl bromide followed by methanolysis, resulted in the formation of side products 30 and 31 .

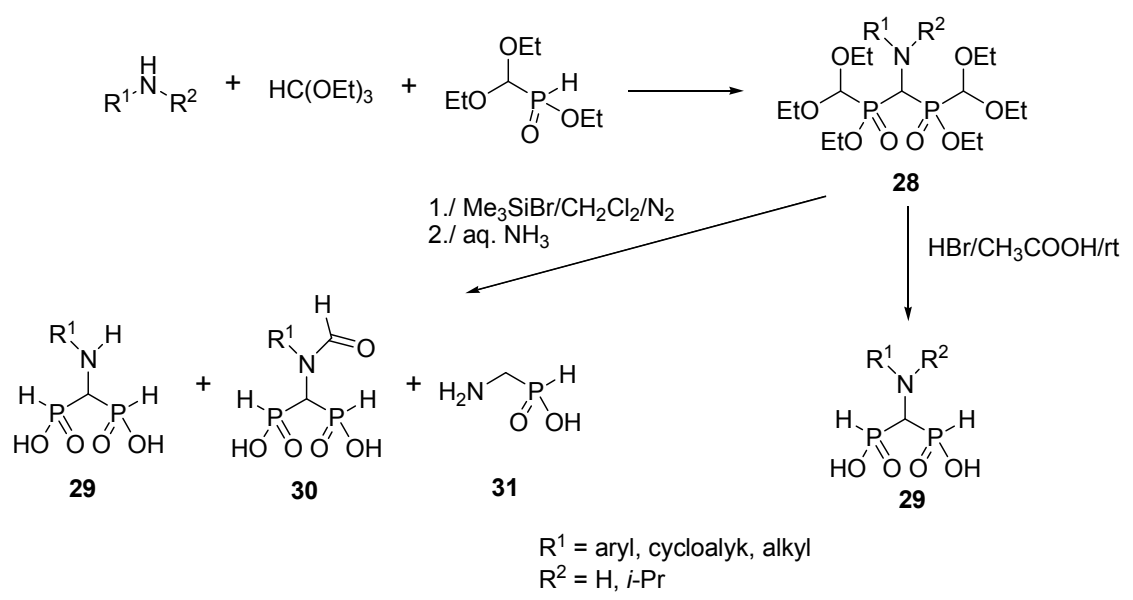

Scheme 17. Three-component synthesis of aminobisphosphonates.

\subsection{Addition of Amines to Vinylidenebisphosphonates}

Tetraethyl vinylidenebisphosphonate 32 is a versatile synthon useful for preparation of a wide variety of bisphosphonates. Its usefulness is a subject of recent comprehensive review [102]. As an electron-deficient alkene, it can undergo conjugate addition of strong and mild nucleophiles, with amines belonging to the latter class. Primary amines undergo smooth Michael addition (Scheme 18), however, the obtained compounds 33 must be quickly purified and hydrolyzed since they tend to undergo a retro-Michael reaction [103,104]. Fortunately, free acids $\mathbf{3 4}$ are substantially more stable.

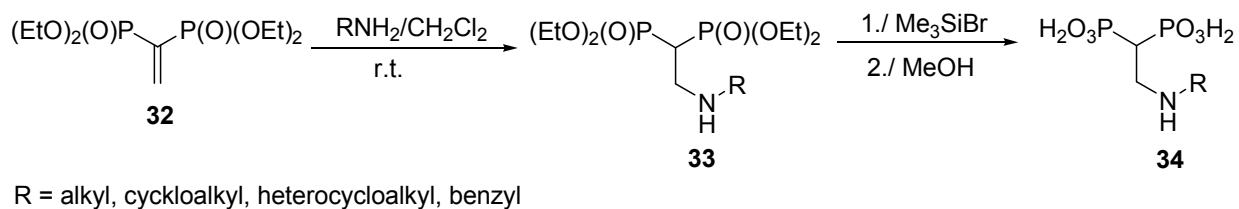

Scheme 18. Michael addition of amines to vinylidenebisphosphonate.

The reactivity of vinylidenebisphosphonates has been used for the synthesis of derivatives of various analogues of fluoroquinolone antibacterial agents [105,106], heteroaromatics with potential pharmaceutical applications [107,108], simple antiplasmodial agents [103,104], HIV reverse transcriptase inhibitors [59,93], potential anti-osteoporotic agents $[109,110]$, and $N$-alkylated antitumor pyridines [111]. Some representatives of these compounds (35-39) are shown in Scheme 19.

Another example, albeit far less developed, is the addition of organometallic amines to vinylidenebisphosphonate 22 (Scheme 20) [112]. Huisgen copper-catalyzed 1,3-dipolar cycloaddition of this bisphosphonate to azides was used to obtain substrate $\mathbf{4 0}$ for a "click reaction". This reaction yielded compounds that may be considered aza-analogues $\mathbf{4 1}$ of zoledronate (Scheme 20) [113]. Similar substrates could also be obtained by addition of propargylamine to the double bond of vinylidenebisphosphonate [114]. 


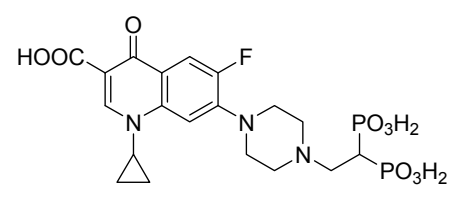

35, analog of Ciprofloxacin<smiles>NCCCNCCCCNCCCNC(P(=O)(O)O)P(=O)(O)O</smiles>

37, potential antiosteoporotic agent

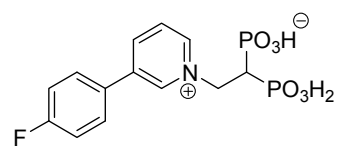

38, anticancer agent<smiles>CCCCCCCCNCC(=O)OP(=O)(O)O</smiles>

36, antiprotozoal agent<smiles>CSc1ncnc2cc(-c3ccccc3)c(O)nc12</smiles>

39, inhibitor of HIV reverse transcriptase

Scheme 19. Representatives of useful bisphosphonates obtained via addition of amines to vinylidenebisphosphonate.

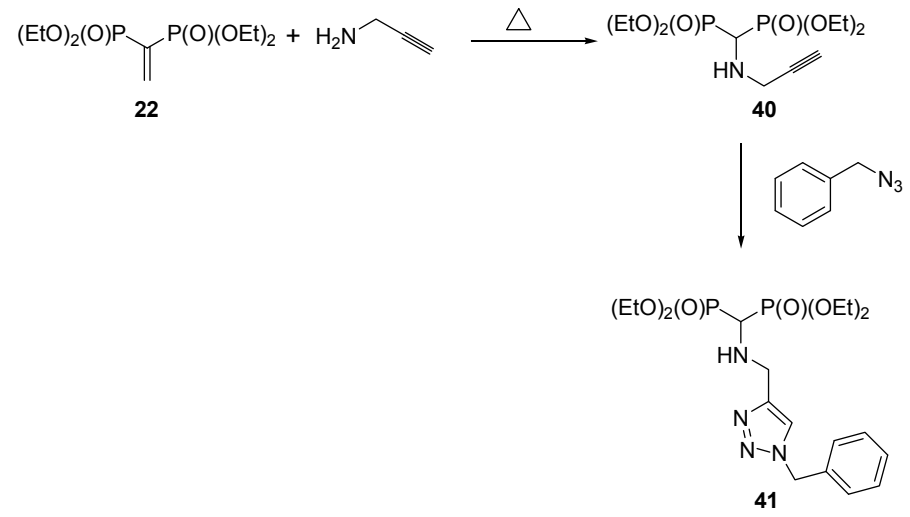

Scheme 20. An example of the synthesis of novel bisphosphonates via "click chemistry".

\subsection{Miscellaneous Procedures}

The desire to obtain new aminobisphosphonate scaffolds for biological studies has stimulated numerous studies on general methods of their synthesis. The methods discussed here are mostly designed to prepare specific scaffolds or are applicable only to specific, if not unusual, substrates. Only some of them may be considered as novel, general procedures.

Radical addition of sodium hypophosphite to terminal alkynes in the presence of triethylborane, which produced 1-alkyl-1,1-bis- $H$-phosphinates in moderate yields, gives access to a wide structural variety of bisphosphonates [115]. When using propargylamino acids, the corresponding bisphosphinates were obtained in satisfactory yields (a representative example is given in Scheme 21 for analogue $\mathbf{4 2}$ of pamidronate). Bisphosphinates are easily converted to bisphosphonates by ozonolysis.

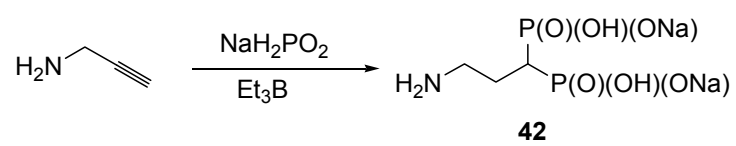

Scheme 21. Procedure for the synthesis of bisphosphinates and their conversion into bisphosphonates.

1-( $N$-acylamino)alkylphosphonates, easily accessible from $N$-acyl- $\alpha$-amino acids using a two-step transformation, underwent electrophilic activation at the $\alpha$-carbon by electrochemical $\alpha$-methoxylation 
in methanol in a process mediated by $\mathrm{NaCl}$. Attempts to carry out a Michaelis-Arbuzov-like reaction of the obtained diethyl 1-(N-acetylamino)-1-methoxy-alkylphosphonates with triethyl phosphite failed; however, they readily reacted with triphenylphosphine (Scheme 22) [116]. The resulting diethyl 1-( $N$-acetylamino)-1-triphenylphosphoniumalkylphosphonate tetrafluoroborates 43 reacted smoothly with trialkyl phosphites, dialkyl phosphonites or alkyl phosphinites in the presence of Hünig's base and methyltriphenylphosphonium iodide as catalysts. This gave bisphosphonates 44, 1-phosphinylalkylphosphonates or 1-phosphinoylalkylphosphonates in good yields. This reaction has potential to become a general procedure.

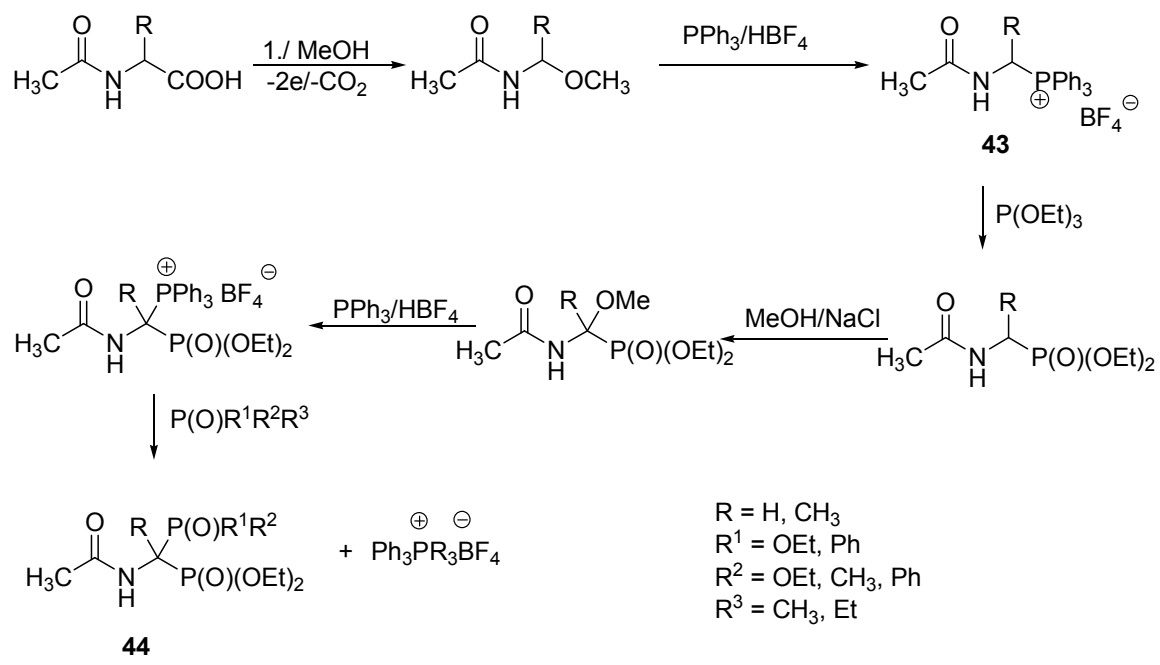

Scheme 22. Transformation of diethyl 1-(N-acetylamino)-1-alkylphosphonates into bisphosphoric acid esters via the corresponding phosphonium salts.

Alkylation of tetraalkyl methylenebisphosphonate 45, a classical method for synthesizing variable bisphosphonic acids, has been rarely used for the synthesis of amino derivatives. Thus, its direct amination with the hydroxylamine ester of diphenylphosphinic acid, followed by its bromoacetylation (Scheme 23), provided substrate $\mathbf{4 6}$ for functionalization into glycopeptide antibiotics, in the hope that they will find an application as medication for osteomyelitis [117]. Another classical example is the monoalkylation of tetraisopropyl methylenebisphosphonate with 1,6-dibromohexane, followed by fluorination with Selectofluor and conversion of the remaining bromide into amine, which resulted in compound 47 (Scheme 23) [118].

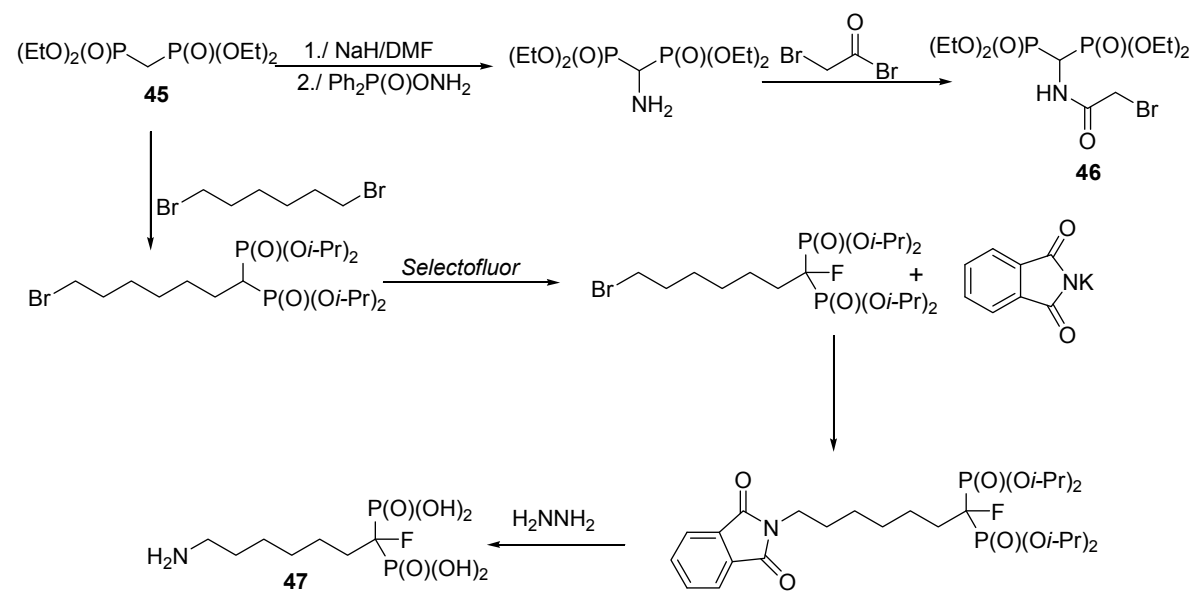

Scheme 23. Synthesis of aminobisphosphonates via alkylation of tetraalkyl methylenebisphosphonates. 
An unusual procedure is metallacarbenoid insertion of aromatic amines into tetraethyl diphosphonodiazomethane 48, which yields corresponding aminomethylenebisphosphonates 49 (Scheme 24) [119]. Among the tested catalysts, $\mathrm{Rh}_{2}\left(\mathrm{NHCOCF}_{3}\right)_{4}$ was found to be the best.

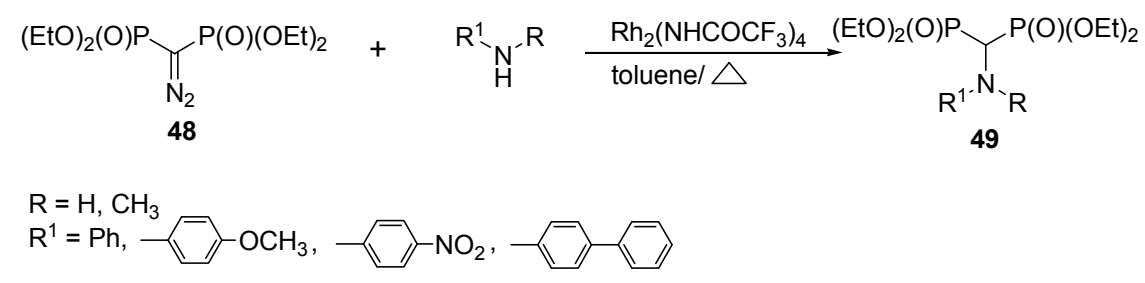

Scheme 24. N-H insertion of the reaction of aromatic amines.

A specific and unexpected reaction was the addition of silylated dialkyl phosphites to 4-phosphono-1-aza-1,3-dienes 50, which resulted in $\gamma$-phosphono- $\alpha$-aminobisphosphonates $\mathbf{5 1}$ (Scheme 25) [120]. This reaction is interesting in that, depending on the steric demand of the substituent present on nitrogen, double 1,2-addition or tandem 1,4-1,2-addition with formation of bisphosphonate 52 occurred (Scheme 25).

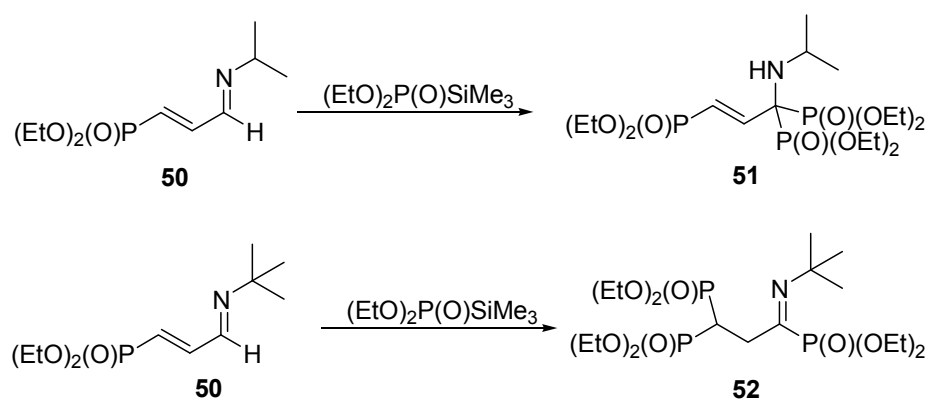

Scheme 25. Addition of phosphites to 4-phosphono-1-aza-1,3-dienes.

Additionally, the addition of phosphites to iminophosphonate esters has been studied. This reaction is limited to specific substrates, and usually the obtained bisphosphonates $\mathbf{5 3}$ are unstable, and phosphoryl C-N transfer to compounds 54 is observed (Scheme 26), which may be considered an example of an aza-Perkov reaction [121-123].

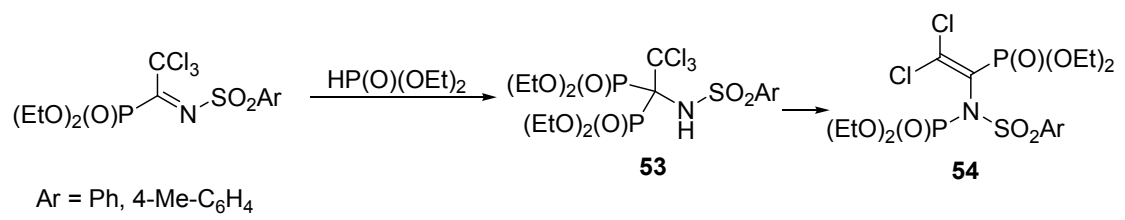

Scheme 26. Addition of phosphites to iminophosphonates.

Finally, syntheses of rare aminomethyltrisphosphonates are presented in a recent review by Romanenko and Kukhar devoted to applications of methylidynetrisphosphonates [124]. Two procedures for the synthesis of bis- and trisphosphonates $\mathbf{5 5}$ and $\mathbf{5 6}$ taken from this review and described in patent literature are depicted in Scheme 27. 


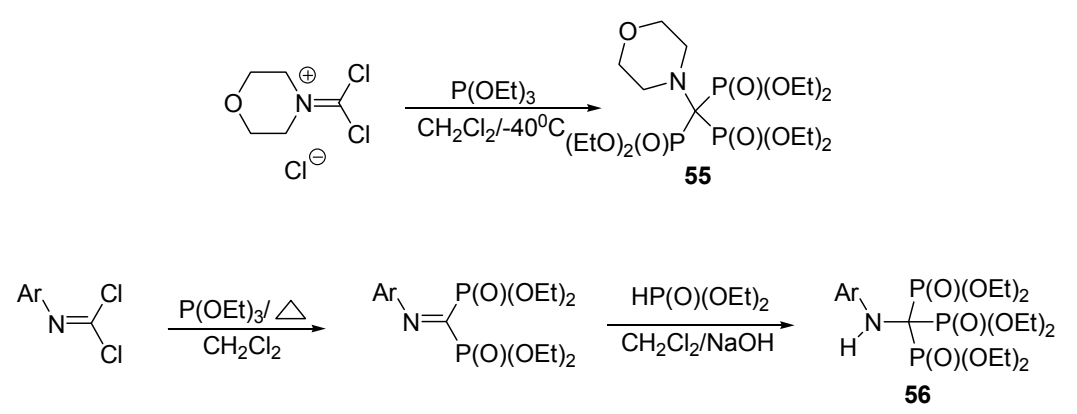

Scheme 27. Syntheses of aminomethyltrisphosphonates.

\section{Functionalization of Aminobisphosphonates}

Bisphosphonates are known for their affinity to bone tissue, and thus their conjugation to various drugs has been quite intensively studied; they are expected to serve as system-targeting drugs [6]. Because dronic acids are produced at industrial scale and are thus readily available and inexpensive, they are most frequently used for that purpose. However, their extreme hydrophilic character means that they are practically insoluble in most organic solvents, which limits the use of aqueous media or requires their conversion into phosphonate esters prior to functionalization. Unfortunately, the methods for direct esterification of phosphonate moieties are scarce and usually give unsatisfactory results; these esters must generally be synthesized independently.

Methods for functionalizing aminobisphosphonic acids with structurally variable molecules were recently reviewed [12]; therefore, in this review, the methods arbitrarily chosen as the most representative are reported.

\subsection{Direct Acylation of Aminobisphosphonic Acids}

Direct acylation of aminobisphosphonic acids is difficult because this reaction is accompanied by the possible competitive acylation of phosphonic groups $[125,126]$ and hydroxylic groups when amino-1-hydroxy-1,1-bisphosphonic acids are substrates [126,127]. A representative example of this reaction is given in Scheme 28 for alendronic acid 57.

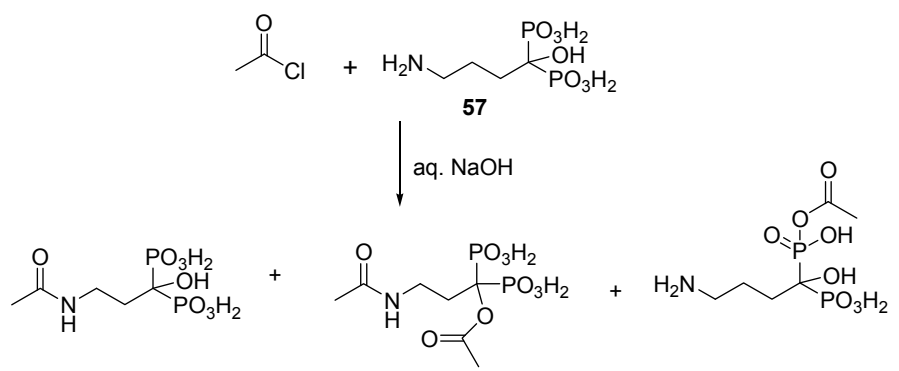

Scheme 28. Direct acylation of alendronic acid with indication of possible side-products.

Acylation of dronic acid salts with acyl chlorides in sodium hydroxide in water or in water/propanol solutions is the simple Schotten-Baumann variant $[127,128]$. Acidification of the solution results in the precipitation of the desired acids or their monosodium salts. To conjugate aminobisphosphonic acids with molecules bearing carboxylic groups, classical coupling protocols used in peptide synthesis have also been used. These include the activation of carboxylic groups with $N, N^{\prime}$-dicyclohexylcarbodiimide (DCC) $[129,130]$; the use of previously prepared succinimidate esters to obtain 21 extremely complex fluorescent imaging probes (representative examples of a green fluorescent dye $\mathbf{5 8}$ and a red fluorescent dye 59 are shown in Scheme 29) [131]; and $N, N^{\prime}$-dicarbonylimidazole, which was used to conjugate 
pamidronate to pullan (polysaccharide composed of maltotriose units) [132] to obtain a system for bone regeneration.

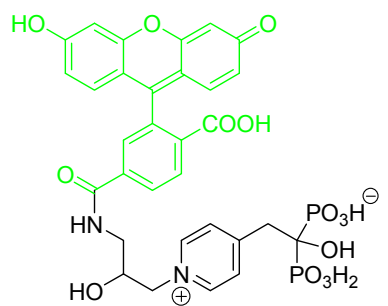

58, derivative of Carboxyfluorescein

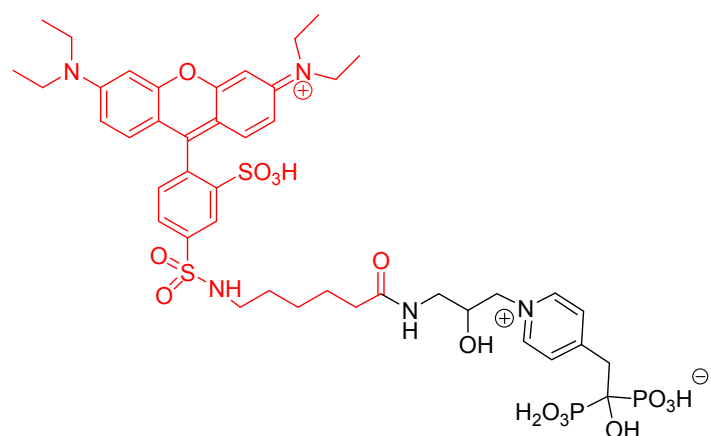

59, derivative of Rhodamine Red $-\mathrm{X}$

Scheme 29. Representative fluorescent imaging probes obtained via acylation of bisphosphonic acids (green—carboxyfluoresceine fragment, red—rhodamine Red-X fragment).

Acylation of aminobisphosphonic acids with small acids, such as acrylic acid [133], chloroacetic acid [134] or succinic acid [135], provided useful substrates for further functionalization of larger molecules, such as macrocycles devised for lanthanide ion complexation, chitosan, and hyaluronan.

\subsection{Direct Acylation of Tetraethyl Aminobisphosphonates}

Esters are far more suitable substrates for acylation than free phosphonic acids, with tetraethyl aminomethylenebisphosphonate being the most popular substrate. It has been used to obtain structurally variable conjugates with estradiol (compounds 60, 61 and 62 in Scheme 30) using classical peptide synthesis coupling agents such as DCC and DPPA (diphenylphosphoryl azide) [136]. These conjugates were synthesized as bone-specific estrogens in the hope that they will protect elderly women from bone loss resulting from osteoporosis.
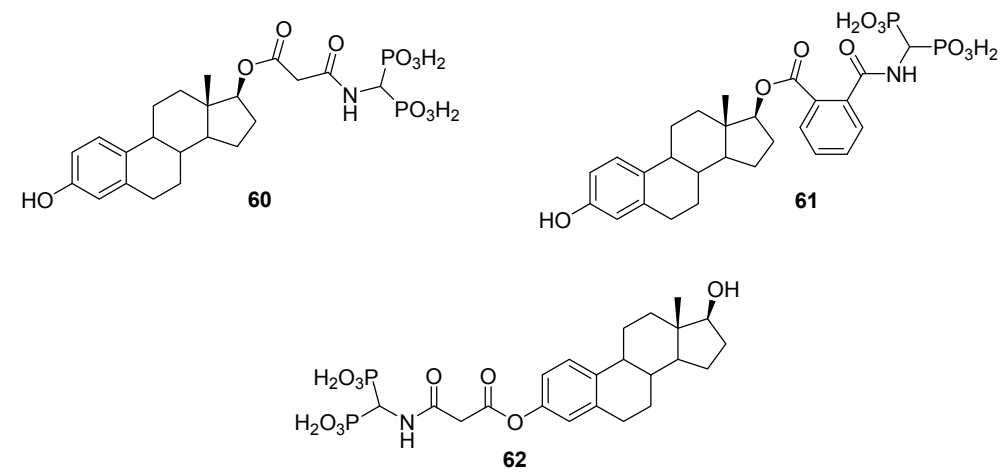

Scheme 30. Representative structures of bone-specific estrogens.

A derivative of raloxifene, a selective estrogen receptor or modulator, was obtained using a suitable acid chloride as substrate [137], whereas radioligands, which are selectively bound to bone tissue, have been synthesized by using DCC/HOBt (hydroxybenzotriazol) activation [138] and antibacterial bisphosphonated benzoxazinorifamycin prodrugs using EDCl (1-ethyl-3-(3dimethylaminopropyl)carbodiimide) [139].

In this case, acylation of aminobisphosphonic acids with small acids was also applied as a starting step to produce antibacterial agents against osteomyelitis [88] and bone imaging macrocycles [81], using acid chlorides as acylating agents. 
Using DCC as a coupling agent, diethyl 1-(2-aminoethylamino)-1,1-ethylbisphosphonate was acylated by structurally variable natural acids, such as folic acid $[140,141]$, ursulonic and betulinic acids [142], and trolox [141,143].

Acylation of pamidronic acid ester 22 by using HBTU (2-(1H-benzotriazol-1-yl)-1,1,3,3tetramethyluronium hexafluorophosphate) was used to prepare a catecholic derivative, which was then bound to the surface of magnetic iron oxide nanoparticles (Scheme 31) [144]. The particle 63 has been designed to remove uranyl ions from blood.

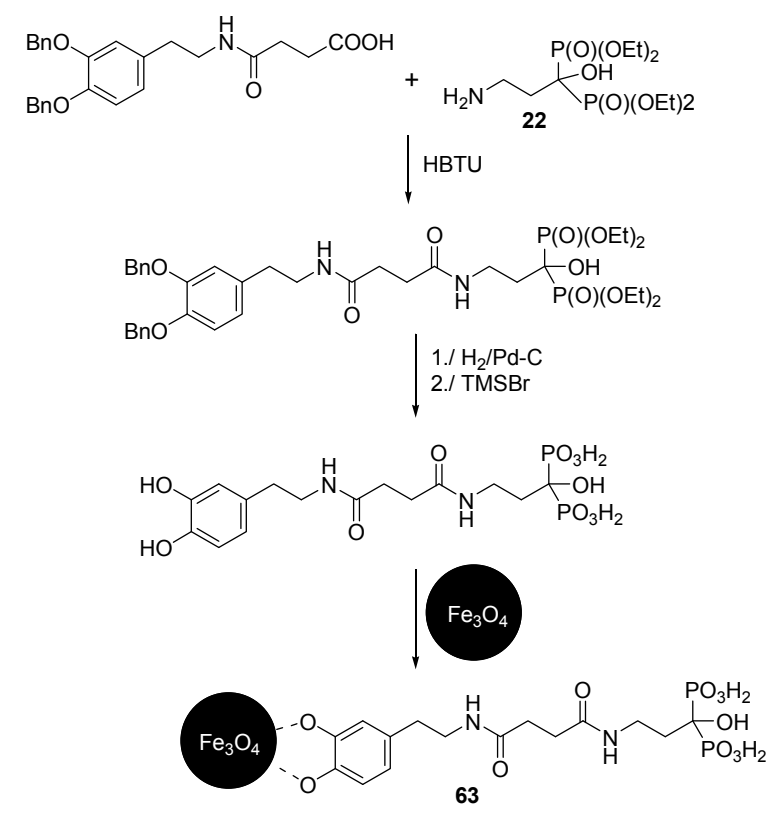

Scheme 31. Synthesis of bisphosphonate functionalized magnetic nanoparticles.

\subsection{Synthesis of Building Blocks for Polymer Chemistry}

Self-etching adhesives are polymeric materials containing phosphonate groups that have become popular in restorative dentistry because they allow strong bonds between dental hard tissues (enamel and dentin). One possibility for their preparation is to obtain monomers containing phosphonic groups [145]. Such methacrylamide monomers 64 and 65 were synthesized by acylation with suitable acryloylchlorides (Scheme 32) [146]. Studies of their photopolymerization indicated that they may be suitable for potential use in dentistry.<smiles>C=C(C)C(=O)NC([18OH])[18OH]</smiles><smiles>O=C1C=C(C(=O)NC(P)P(=O)(O)O)C=C(C(=O)NC(PO)P(=O)(O)O)CO1</smiles>

Scheme 32. Bisphosphonylated methacrylamide monomers.

A similar monomer, acryloylated pamidronate, has been used to obtain a hyaluronic acid derivative that is dually polymerized with cross-linkable hydrazide groups and bisphosphonate ligands. By mixing bisphosphonate polymer with calcium ions and aldehyde-derivatized hyaluronic acid, a hybrid hydrogel was obtained, which quickly mineralizes [147]. Such a system is of interest as a mediator for fast bone regeneration.

By dispersion copolymerization of three monomers (methacrylate bisphosphonate 66, $\mathrm{N}$-(3aminopropyl) methacrylamide 67, and tetra(ethylene glycol) diacrylate 68) (Scheme 33), polymeric nanoparticles 69 were obtained [148]. Their size distribution was controlled by changing various 
polymerization parameters. By covalent attachment of a drug and/or a dye to amino groups (such as a near IR fluorescent dye), a theranostic system may be obtained.<smiles>[X]C([PH])(COCC(C)(CC)OC(=O)C(=C)C)[Po]([O-])([O-])O</smiles>

66<smiles>C=C(C)C(=C)CCCCN</smiles><smiles>C=CC(=O)OCC(C)OC(=O)C=C</smiles>

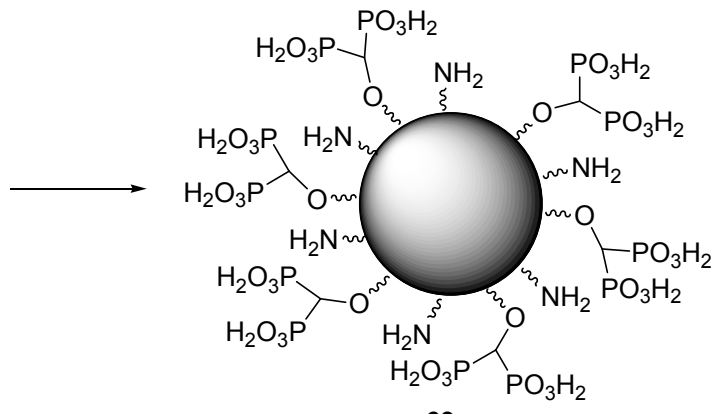

69

Scheme 33. Synthesis of polymeric nanoparticles as potential dye and drug carriers.

Macromolecular co-conjugates of bisphosphonate and ferrocene were synthesized by means of Michael addition copolymerization of methylenebisacrylamide (MBA) with primary amines-6amino-1-hydroxyhexylidene-1,1-bisphosphonate and 4-ferrocenyl-butamidopropylamine [149]. The mass percentage incorporation of ferrocene analogues was found to be between $4 \%-5 \%$, and $10 \%-12 \%$ for bisphosphonate. Such polymers could be selectively bound to bone tissue and slowly release anticancer ferrocene derivatives at this target site.

\subsection{Miscellaneous}

Other means to functionalize amino moieties are quite scarce and dispersed. Classical ones include the formation of Schiff bases, which are then alkylated [150] or reduced [126], and synthesis of thioureido derivatives as intermediates in the preparation of heterocyclic compounds [151-153].

The functionalization of polysaccharides is the gateway of aminobisphosphonates into nanoscience. For example, phosphonated cellulose was utilized to obtain nanocellulose with good thermal stability and potential intumescent properties. It was synthesized from birch pulp via sequential periodate oxidation and reductive amination using alendronate 57 as a phosphonating reagent (Scheme 34) [154]. After high-pressure homogenization, bisphosphonate cellulose nanofibers or nanocrystals of the general formula $\mathbf{7 0}$ were obtained, depending on the initial oxidation degree.

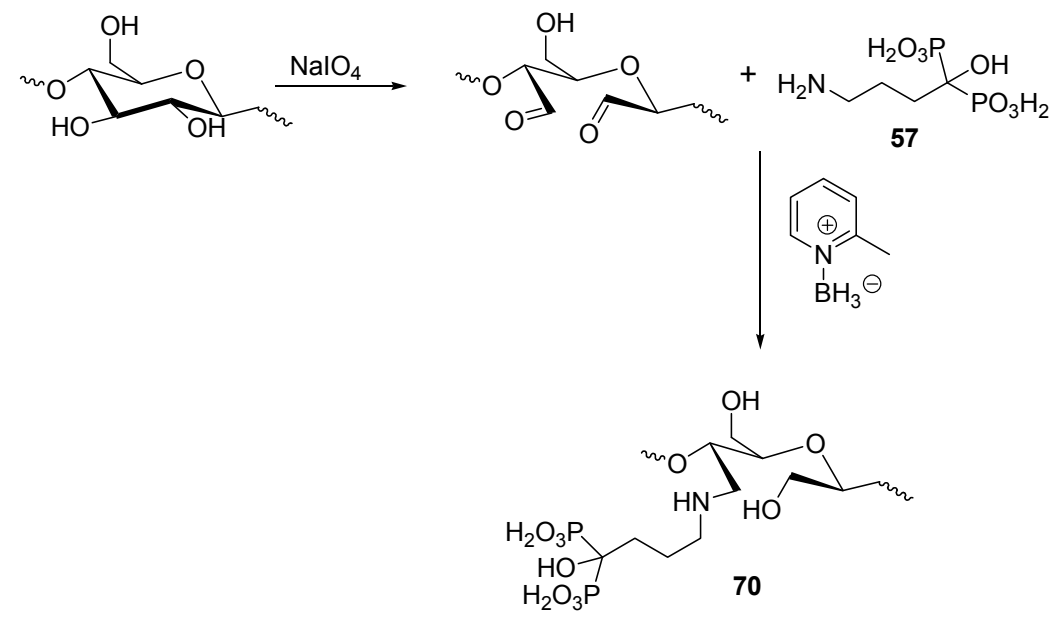

Scheme 34. Periodate oxidation of cellulose followed by reductive amination with sodium alendronate. 
Alendronate was also bound to conjugates of pullulan and paclitaxel, which were bound to the polysaccharide by a cathepsin K-sensitive tetrapeptide spacer. This should ensure release of paclitaxel in bones. Then, bisphosphonate was covalently conjugated to the sugar chain via a polyethyleneglycol chain, using a technique similar to that described above (identical to those shown in Scheme 34) [155]. This system exhibited strong antiproliferative action against several cancer cell lines.

\section{Conclusions}

Aminobisphosphonic acids are gaining significant interest as a class of compounds with promising physiologic activity, with some representatives already commercialized as bone resorption inhibitors, and therefore useful drugs against osteoporosis and related bone disorders. This leads to both the modification of existing and the elaboration of novel procedures for their preparation. There are several commonly used reactions for this purpose; however, they have also been modified in the last decade to be tailored to specific biological needs. A few novel procedures have also been developed. Functionalization of simple aminobisphosphonic acids is a difficult task because of their strongly polar character. However, successful examples of functionalization of the amino moieties of these compounds have provided promising diagnostics and novel therapeutic agents.

Acknowledgments: This work was supported by a statuary activity subsidy from the Polish Ministry of Science and Higher Education.

Conflicts of Interest: The authors declare no conflict of interest.

\section{References}

1. Turhanen, P.A. Synthesis of triple bond containing 1-hydroxy-1,1-bisphosphonic acid derivatives to be used as precursors in "click" chemistry: Two examples. J. Org. Chem. 2014, 79, 6330-6335. [CrossRef] [PubMed]

2. Russell, R.G. Bisphosphonates: The first 40 years. Bone 2011, 49, 2-19. [CrossRef] [PubMed]

3. Ebetino, F.H.; Hogan, A.M.; Sun, S.; Tsuompra, M.K.; Duan, X.; Triffitt, J.T.; Kwaasi, A.A.; Dunford, J.E.; Barnett, B.L.; Oppermann, U.; et al. The relationship between the chemistry and biological activity of the bisphosphonates. Bone 2011, 49, 20-33. [CrossRef] [PubMed]

4. Maraka, S.; Kennel, K.A. Bisphosphonates for the prevention and treatment of osteoporosis. Br. Med. J. 2015, 351, h3783. [CrossRef] [PubMed]

5. Shi, C.G.; Zhang, Y.; Yuan, W. Efficacy of bisphosphonates on bone mineral density and fracture Rate in patients with osteogenesis imperfecta: A systematic review and meta-analysis. Am. J. Ther. 2016, 3, e894-e904. [CrossRef] [PubMed]

6. Chmielewska, E.; Kafarski, P. Physiologic Activity of Bisphosphonates-Recent Advances. Open Pharm. Sci. J. 2016, 3, 56-78. [CrossRef]

7. Demkowicz, S.; Rachon, J.; Daśko, M.; Kozak, W. Selected organophosphorus compounds with biological activity. Applications in medicine. RSC Adv. 2016, 6, 7101-7112. [CrossRef]

8. Studnik, H.; Liebsch, S.; Forlani, G.; Wieczorek, D.; Kafarski, P.; Lipok, J. Amino polyphosphonatesChemical features and practical uses, environmental durability and biodegradation. New Biotechnol. 2015, 32, 1-6. [CrossRef] [PubMed]

9. Turhanen, P.A.; Vepsäläinen, J.J.; Peräniemi, S. Advanced material and approach for metal ions removal from aqueous solutions. Sci. Rep. 2015, 5. [CrossRef] [PubMed]

10. Gałęzowska, J.; Gumienna-Kontecka, E. Phosphonates, their complexes and bio-applications: A spectrum of surprising diversity. Coord. Chem. Rev. 2012, 256, 105-124. [CrossRef]

11. Abdou, W.M.; Shaddy, A.A. The development of bisphosphonates for therapeutic uses, and bisphosphonate structure-activity consideration. Arch. Org. Chem. 2008, 2009, 143-182.

12. Romaneneko, V.D.; Kukhar, V.A. 1-Amino-1,1-bisphosphonates. Fundamental syntheses and new developments. Arch. Org. Chem. 2012, 2012, 127-166.

13. Petroianu, G.A. Pharmacist Theodor Salzer (1833-1900) and the discovery of bisphosphonates. Pharmazie 2011, 66, 804-807. [PubMed] 
14. Kieczykowski, G.R.; Jobson, R.B.; Melillo, D.G.; Reinhold, D.F.; Grenda, V.J.; Shinkai, I. Preparation of (4-amino-1-hydroxybutylidene)bisphosphonic acid sodium salt, MK-217 (alendronate sodium). An improved procedure for the preparation of 1-hydroxy-1,1-bisphosphonic acids. J. Org. Chem. 1995, 60, 8310-8312. [CrossRef]

15. Teixeira, F.C.; Antunes, I.F.; Curto, M.J.M.; Neves, M.; Teixeira, A.P.S. Novel 1-hydroxy-1,1-bisphosphonates derived from indazole: Synthesis and characterization. Arch. Org. Chem. 2009, 2009, 69-84.

16. Yanvarev, D.V.; Koovina, A.N.; Usanov, N.N.; Kochetkov, S.N. Non-hydrolysable analogues of inorganic pyrophosphate as inhibitors of Hepatitis C virus RNA-dependent RNA polymerase. Russ. J. Bioorg. Chem. 2012, 38, 224-229. [CrossRef]

17. Srinivasa Rao, D.V.N.; Dandala, R.; Narayan, G.K.A.S.S.; Lenin, R.; Sivakumaran, N.; Naidu, A. Novel procedure for the synthesis of 1-hydroxy-1,1-bisphosphonic acids using phenols as medium. Synth. Commun. 2007, 37, 4359-4365. [CrossRef]

18. Grün, A.; Nagy, D.I.; Németh, O.; Mucsi, Z.; Garadnay, S.; Greiner, I.; Keglevich, G. The Synthesis of 3-Phenylpropidronate Applying Phosphorus Trichloride and Phosphorous Acid in Methanesulfonic Acid. Curr. Org. Chem. 2016, 20, 1745-1752. [CrossRef]

19. Lecouvey, M.; Leroux, I. Synthesis of 1-hydroxy-1,1-bisphosphonates. Heteroat. Chem. 2000, 11, 556-561. [CrossRef]

20. Keglevich, G.; Grün, A.; Kovács, R.; Garadnay, S.; Greiner, I. Green chemical synthesis of bisphosphonic/ dronic derivatives. Phosphorus Sulfur Silicon Relat. Elem. 2015, 190, 664-667. [CrossRef]

21. Troev, K.; Todorov, P.; Naydenova, E.; Mitova, V.; Vassiliev, N. A study of the reaction of phosphorus trichloride with paraformaldehyde in the presence of carboxylic acids. Phosphorus Sulfur Silicon Relat. Elem. 2013, 188, 1147-1155. [CrossRef]

22. Nagy, D.I.; Grün, A.; Garadnay, S.; Greiner, I.; Keglevich, G. Synthesis of hydroxymethylenebisphosphonic acid derivatives in different solvents. Molecules 2016, 21, 1046. [CrossRef] [PubMed]

23. Kachbi Khelfallah, S.; Monteil, M.; Deschamp, J.; Gager, O.; Migianu-Griffoni, E.; Lecouvey, M. Synthesis of novel polymerisable molecules bearing bisphosphonate. Org. Biomol. Chem. 2015, 13, 11382-11392. [CrossRef] [PubMed]

24. Grün, A.; Kovács, R.; Nagy, D.L.; Garadnay, S.; Greiner, I.; Keglevich, G. Efficient synthesis of benzidronate applying of phosphorus trichloride and phosphorous acid. Lett. Drug Des. Discov. 2015, 12, 78-84. [CrossRef]

25. Keglevich, G.; Grün, A.; Aradi, K.; Garadnay, S.; Greiner, I. Optimized synthesis of N-heterocyclic dronic acids; closing a black-box era. Tetrahedron Lett. 2011, 21, 2744-2746. [CrossRef]

26. Keglevich, G.; Grün, A.; Garadnay, S.; Greiner, I. Rational synthesis of dronic acid derivatives. Phosphorus Sulfur Silicon Relat. Elem. 2015, 190, 2116-2124. [CrossRef]

27. Ratrout, S.S.; Al Sarabi, A.L.; Sweidan, K.A. A one-pot and efficient synthesis of zolendronic acid starting from tert-butyl imodazol-1-yl acetate. Pharm. Chem. J. 2015, 48, 837-841. [CrossRef]

28. Mizrahi, D.A.; Waner, T.; Segall, Y. $\alpha$-Amino acid derived bisphosphonates: Synthesis and anti-resorptive activity. Phosphorus Sulfur Silicon Relat. Elem. 2001, 173, 1-25. [CrossRef]

29. Lenin, R.; Raju, M.R.; Srinisava Rao, D.V.N.; Ray, U.K. Microvawe-assistant efficient synthesis of bisphosphonate libraries: A useful procedure for the preparation of bisphosphonates containing nitrogen and sulfur. Med. Chem. Res. 2013, 22, 1624-1629. [CrossRef]

30. Roth, A.G.; Drescher, A.; Yang, Y.; Redmer, S.; Uhling, S.; Arenz, C. Potent and selective inhibition of acid sphingomyelinase by bisphosphonates. Angew. Chem. Int. Ed. 2009, 48, 7560-7563. [CrossRef] [PubMed]

31. Szajnman, S.H.; Ravaschino, E.L.; Docampo, R.; Rodrigues, J.B. Synthesis and biological evaluation of 1-amino-1,1-bisphosphonates derived from fatty acids against Trypanosoma cruzi targeting farnesyl pyrophosphate synthase. Bioorg. Med. Chem. Lett. 2005, 15, 4685-4690. [CrossRef] [PubMed]

32. Wu, M.; Chen, P.; Huang, Y. Convenient synthesis of analogs of aminomethylene gem-diphosphonic acid from amines without catalyst. Synth. Commun. 2004, 34, 1393-1398. [CrossRef]

33. Fukuda, M.; Okamoto, Y.; Sakurai, H. Synthesis of dialkylaminomethylenediphosphonic acids. Bull. Chem. Soc. Jpn. 1975, 48, 1030-1031. [CrossRef]

34. Yu, C.M.; Wang, B.; Chen, Z.W. A Novel synthesis of alkylamino substituted methylenediphosphonates using bis(trichloromethyl) carbonate and RCONR ${ }^{1} \mathrm{R}^{2}$. Chin. J. Chem. 2008, 26, 1899-1901. [CrossRef]

35. Plöger, W.; Schindler, N.; Wollmann, K.; Worms, K.H. Herstellung von 1-Aminoalkan-1,1-diphosphonsäuren. Z. Anorg. Allg. Chem. 1972, 389, 119-128. [CrossRef] 
36. Olive, G.; le Moigne, F.; Mercier, A.; Rockenbauer, A.; Tordo, P. Synthesis of tetraalkyl (pyrrolidine-2,2-diyl) bisphosphonates and 2,2-bis(diethoxyphosphoryl)-3,4-dihydro-2H-pyrrole 1-oxide; ESR study of derived nitroxides. J. Org. Chem. 1998, 63, 9095-9099. [CrossRef]

37. Olive, G.; Jacques, A. Tetraethyl(pyrrolidine-2,2-diyl)bisphosphonate. Molecules 2001, 6, M275. [CrossRef]

38. Olive, G.; Jacques, A. Optimization, continuation and lack of the one-step diphosphorylation reaction assay of modification of the tetraethyl(pyrrolidine-2,2-diyl)bisphosphonate. Phosphorus Sulfur Silicon Relat. Elem. 2003, 178, 33-46. [CrossRef]

39. Olive, G.; Rockenbauer, A.; Rozanska, X.; Jacques, A.; Peeters, D.; German, A. Synthesis of new tetraethyl( $N$-alkyl-1-aminoethan-1,1-diyl)bisphosphonates and ESR analysis of chemical exchange of derived nitroxides of acyclic aminobisphosphonates. Phosphorus Sulfur Silicon Relat. Elem. 2008, 182, 2359-2369. [CrossRef]

40. Wang, A.-E.; Chang, Z.; Sun, W.-T.; Huang, P.-Q. General and chemoselective bisphosphonylation of secondary and tertiary amides. Org. Lett. 2015, 17, 732-735. [CrossRef] [PubMed]

41. Prishchenko, A.A.; Livantsov, N.V.; Novikova, O.P.; Livantsova, L.I.; Petrosyan, V.S. Synthesis of the new types of $\mathrm{N}$-substituted aminomethylenebisorganophosphorus acids and their derivatives. Heteroatom Chem. 2009, 20, 319-324. [CrossRef]

42. Prishchenko, A.A.; Livantsov, N.V.; Novikova, O.P.; Livantsova, L.I.; Ershov, I.R.; Petrosyan, V.S. Synthesis and reactivity of the new trimethylsilyl esters of aminomethylenebisorganophosphorus acids. Heteroatom Chem. 2013, 24, 355-360. [CrossRef]

43. Prishchenko, A.A.; Livantsov, N.V.; Novikova, O.P.; Livantsova, L.I.; Petrosyan, V.S. Synthesis of aminomethylenediphosphonates and their derivatives containing $\mathrm{PCNH}_{2}$ fragments. J. Gen. Chem. 2014, 83, 608-610. [CrossRef]

44. Chmielewska, E.; Miszczyk, P.; Kozłowska, J.; Prokopowicz, M.; Młynarz, P.; Kafarski, P. Reaction of benzolactams with triethyl phosphite prompted by phosphoryl chloride affords benzoannulated monophosphonates instead of expected bisphosphonates. J. Organomet. Chem. 2015, 785, 84-91. [CrossRef]

45. Prishchenko, A.A.; Livantsov, N.V.; Novikova, O.P.; Livantsova, L.I.; Ershov, I.R.; Petrosyan, V.S. Synthesis of new types of aminomethylenediphosphorus-containing acids and their derivatives. Russ. J. Gen. Chem. 2015, 85, 370-379. [CrossRef]

46. Du, Y.; Jung, K.Y.; Wimer, D.F. A one-flask synthesis of $\alpha, \alpha$-bisphosphonates via enolate chemistry. Tetrahedron Lett. 2002, 43, 8665-8668. [CrossRef]

47. Srinivasa Rao, D.V.N.; Dandala, R.; Lenin, R.; Sivakumaran, N.; Shivashankar, S.; Naidu, A. A facile one pot synthesis of bisphosphonic acids and their sodium salts from nitriles. Arch. Org. Chem. 2007, 2007, 34-38.

48. Kaabak, L.V.; Kuz'mina, N.E.; Khudneko, A.V.; Tomilov, A.P. Improved synthesis of 1-aminoethylidenediphosphonic acid. Russ. J. Gen. Chem. 2006, 76, 1673-1674. [CrossRef]

49. Bandurina, T.A.; Konyukhov, V.N.; Panomareva, O.A.; Barybin, O.S.; Pushkareva, Z.N. Synthesis and antitumor activity of aminophosphonic acids. Pharm. Chem. J. 1978, 12, 1428-1431. [CrossRef]

50. Midier, C.; Lantsoght, M.; Volle, J.-N.; Pirat, J.L.; Virieux, D.; Stevens, C.V. Hydrophosphonylation of alkenes or nitriles by double radical transfer mediated by titanocene/propylene oxide. Tetrahedron Lett. 2011, 52, 6693-6696. [CrossRef]

51. Váradi, A.; Palmer, T.C.; Notis Dardashti, R.; Majumdar, S. Isocyanide-based multicomponent reactions for the synthesis of heterocycles. Molecules 2016, 21, 19. [CrossRef] [PubMed]

52. Hirai, T.; Han, L.-B. Palladium-catalyzed insertion of isocyanides into $\mathrm{P}(\mathrm{O})-\mathrm{H}$ bonds: Selective formation of phosphinoyl imines and bisphosphinoylaminomethanes. J. Am. Chem. Soc. 2006, 128, 7422-7423. [CrossRef] [PubMed]

53. Goldemen, W.; Kluczyński, A.; Soroka, M. The preparation of N-substituted aminomethylidenebisphosphonates and their tetraalkyl esters via reaction of isonitriles with trialkyl phosphites and hydrogen chloride. Part 1. Tetrahedron Lett. 2012, 53, 5290-5292.

54. Goldeman, W.; Nasulewicz-Goldeman, A. Synthesis and antiproliferative activity of aromatic and aliphatic bis(aminomethylidene(bisphosphonic)) acids. Bioorg. Med. Chem. Lett. 2014, 24, 3475-3479. [CrossRef] [PubMed]

55. Kurzak, B.; Goldeman, W.; Szpak, M.; Matczak-Jon, E.; Kamecka, E. Synthesis of N-methyl alkylaminomethane1,1-diphosphonic acids and evaluation of their complex-formation abilities towards copper(II). Polyhedron 2015, 85, 675-684. [CrossRef] 
56. Goldeman, W.; Nasulewicz-Goldeman, A. Synthesis and biological evaluation of aminomethylidenebisphosphonic derivatives of $\beta$-arylethylamines. Tetrahedron 2015, 71, 3282-3289. [CrossRef]

57. Bhushan, K.R.; Tanaka, E.; Frangioni, J.V. Synthesis of conjugatable bisphosphonates for molecular imaging of large animals. Angew. Chem. Int. Ed. 2007, 46, 7969-7971. [CrossRef] [PubMed]

58. Ziora, Z.; Maly, A.; Lejczak, B.; Kafarski, P.; Holband, J.; Wójcik, G. Reactions of N-phthalylamino acid chlorides with trialkyl phosphites. Heteroatom Chem. 2000, 11, 232-239. [CrossRef]

59. Yanvarev, D.V.; Korovina, A.N.; Usanov, N.N.; Khomich, O.A.; Vepsäläinen, J.; Puljula, E.; Kukhanova, M.K.; Kochetkov, S.N. Data on synthesis of methylene bisphosphonates and screening of their inhibitory activity towards HIV reverse transcriptase. Data Brief 2016, 8, 1157-1167. [CrossRef] [PubMed]

60. Guenin, E.; Degache, E.; Liquier, J.; Lecouvey, M. Synthesis of 1-hydroxymethylene-1,1-bis(phosphonic acids) from acid anhydrides: Preparation of a new cyclic 1-acyloxymethylene-1,1-bis(phosphonic acid). Eur. J. Org. Chem. 2004, 2983-2987. [CrossRef]

61. Kachbi-Khelfallah, S.; Monteil, M.; Cortes-Clerget, M.; Migianu-Griffoni, E.; Pirat, J.-L.; Gager, O.; Deschamp, J.; Lecouvey, M. Towards potential nanoparticle contrast agents: Synthesis of new functionalized PEG bisphosphonates. Beilstein J. Org. Chem. 2016, 12, 1366-1371. [CrossRef] [PubMed]

62. Teixeira, F.C.; Rangel, C.M.; Teixeira, A.P.S. Synthesis of new azole phosphonate precursors for fuel cells proton exchange membranes. Heteroatom Chem. 2015, 26, 238-248. [CrossRef]

63. Teixeira, F.C.; Lucas, C.; Curto, M.J.M.; Neves, M.; Duarte, M.T.; André, V.; Teixeira, A.P.S. New 1-Hydroxy-1,1-bisphosphonates derived from 1H-pyrazolo[3,4-b]pyridine: Synthesis and characterization. J. Braz. Chem. Soc. 2013, 24, 1295-1306. [CrossRef]

64. Kaboudin, B.; Ezzati, A.; Faghihi, M.R.; Barati, A.; Kazemi, F.; Abdollahi, H.; Yokomatsu, T. Hydroxy-bisphosphinic acids: Synthesis and complexation properties with transition metals and lanthanide ions in aqueous solution. J. Iran. Chem. Soc. 2016, 13, 747-752. [CrossRef]

65. Crossey, K.; Migaud, M.E. Solventless synthesis of acyl phosphonamidates, precursors to masked bisphosphonates. Chem. Commun. 2015, 51, 11088-11091. [CrossRef] [PubMed]

66. Egorov, M.; Aoun, S.; Padrines, M.; Redini, F.; Heymann, D.; Lebreton, J.; Mathé-Allainmat, M.A. One-pot synthesis of 1-hydroxy-1,1-bis(phosphonic acid)s starting from the corresponding carboxylic acids. Eur. J. Org. Chem. 2011, 7148-7154. [CrossRef]

67. Suzuki, F.; Fujikawa, Y.; Yamamoto, S.; Mizutani, H.; Funabashi, C.; Ohya, T.; Ikai, T.; Oguchi, T. Pharmaceutical Compositions Containing Geminal Diphosphonates. US 5583122 A, 1 February 1979.

68. Maier, L. Organishe phosphorverbindungen 75: Herstellung und Eigenschaften von Aminomethylendiphosphinaten und -diphosphonaten, $\mathrm{RR}^{1} \mathrm{NCH}\left[\mathrm{P}(\mathrm{O}) \mathrm{R}^{2}\left(\mathrm{OR}^{3}\right)\right]_{2}$ und Derivaten. Phosphorus Sulfur Silicon Relat. Elem. 1981, 11, 311-332. [CrossRef]

69. Kaboudin, B.; Kalipour, S. A microwave-assisted solvent- and catalyst-free synthesis of aminomethylene bisphosphonates. Tetrahedron Lett. 2009, 50, 4243-4245. [CrossRef]

70. Minaeva, L.; Patrikeeva, L.S.; Kabachnik, M.M.; Beletskaya, I.P.; Orlinson, B.S.; Novakov, I.A. Synthesis of novel aminomethylenebisphosphonates and bisphosphonic acids, containing adamantyl fragment. Heteroatom Chem. 2011, 22, 55-58. [CrossRef]

71. Bálint, E.; Tajti, A.; Dziełak, A.; Hägele, G.; Keglevich, G. Microwave-assisted synthesis of (aminomethylene) bisphosphine oxides and (aminomethylene)bisphosphonates by a three-component condensation. Beilstein J. Org. Chem. 2016, 12, 1493-1502. [CrossRef] [PubMed]

72. Reddy, N.B.; Sundar, C.S.; Krishna, B.S.; Reddy, K.M.K.; Reddy, C.S. Synthesis and in-vitro antimicrobial activity of aminomethylene bisphosphonates. Iran. J. Org. Chem. 2014, 6, 1227-1234.

73. Krutikov, V.I.; Erkin, A.V.; Pautov, P.A.; Zolotukhina, M.M. Heteryl- and arylaminomethylenebisphosphonates: Synthesis and biologic activity. Russ. J. Gen. Chem. 2003, 73, 187-191. [CrossRef]

74. Siva Prasad, S.; Jayaprakash, S.H.; Syamasundar, Ch.; Sreelakshmi, P.; Bhuvaneswar, C.; Vijaya Bhaskar, B.; Rajendra, W.; Nayak, S.K.; Suresh Reddy, C. Tween 20-/ $\mathrm{H}_{2} \mathrm{O}$ promoted green synthesis, computational and antibacterial activity of amino acid substituted methylene bisphosphonates. Phosphorus Sulfur Silicon Relat. Elem. 2015, 190, 2040-2050. [CrossRef]

75. Mimura, M.; Hayashida, M.; Nomiyama, K.; Ikegami, S.; Iida, Y.; Tamura, M.; Hiyama, Y.; Ohishi, Y. Synthesis and evaluation of (piperidinomethylene)bis(phosphonic acid) derivatives as anti-osteoporosis agents. Chem. Pharm. Bull. 1993, 41, 1973-1986. [CrossRef] 
76. De Schutter, J.W.; Shaw, J.; Lin, Y.-S.; Tsantrizos, Y.S. Design of potent bisphosphonate inhibitors of the human farnesyl pyrophosphate synthase via targeted interactions with the active site "capping" phenyls. Bioorg. Med. Chem. 2012, 20, 5583-5591. [CrossRef] [PubMed]

77. Leung, C.Y.; Langille, A.M.; Mancuso, J.; Tsantrizos, Y.S. Discovery of thienopyrimidine-based inhibitors of the human farnesyl pyrophosphate synthase-Parallel synthesis of analogs via a trimethylsilyl ylidene intermediate. Bioorg. Med. Chem. 2013, 21, 2229-2240. [CrossRef] [PubMed]

78. Leung, C.Y.; Park, J.; de Schutter, J.W.; Sebag, M.; Berghuis, A.M.; Tsantrizos, Y.S. Thienopyrimidine bisphosphonate (ThPBP) inhibitors of the human farnesyl pyrophosphate synthase: Optimization and characterization of the mode of inhibition. J. Med. Chem. 2013, 56, 7939-7950. [CrossRef] [PubMed]

79. Rubino, M.T.; Agamennone, M.; Campestre, C.; Campiglia, P.; Cremasco, V.; Faccio, R.; Laghezza, A.; Loiodice, F.; Maggi, D.; Panza, E.; et al. Biphenyl sulfonylamino methyl bisphosphonic acids as inhibitors of matrix metalloproteinases and bone resorption. ChemMedChem 2011, 6, 1258-1268. [CrossRef] [PubMed]

80. Tauro, M.; Lagezza, A.; Loiodice, F.; Agamennone, M.; Campestre, C.; Tortorella, P. Arylamino methylene bisphosphonate derivatives as bone seeking matrix metalloproteinase inhibitors. Bioorg. Med. Chem. 2013, 21, 6456-6465. [CrossRef] [PubMed]

81. Chmielewska, E.; Mazur, Z.; Kempińska, K.; Wietrzyk, J.; Piątek, A.; Kuryszko, J.J.; Kiełbowicz, Z.; Kafarski, P. $N$-Arylaminomethylenebisphosphonates bearing fluorine atoms: Synthesis and antiosteoporotic activity. Phosphorus Sulfur Silicon Relat. Elem. 2016, 190. [CrossRef]

82. Chmielewska, E.; Kempińska, K.; Wietrzyk, J.; Piątek, A.; Kuryszko, J.J.; Kiełbowicz, Z.; Kafarski, P. Novel Bisphosphonates and Their Use. WO2015159153 A1, 22 October 2015.

83. Kubiček, V.; Rudovský, J.; Kotek, J.; Hermann, P.; Elst, L.V.; Muller, R.N.; Kolar, Z.I.; Wolterbeek, H.Th.; Peters, J.A.; Lukeš, I. A Bisphosphonate monoamide analogue of DOTA: A potential agent for bone targeting. J. Am. Chem. Soc. 2005, 127, 16477-16485. [CrossRef] [PubMed]

84. Årstad, E.; Hoff, P.; Skattebøl, L.; Skretting, A.; Breistøl, K. Studies on the synthesis and biological properties of non-carrier-added [ ${ }^{125} \mathrm{I}$ and $\left.{ }^{131} \mathrm{I}\right]$-labeled arylalkylidenebisphosphonates: Potent bone-seekers for diagnosis and therapy of malignant osseous lesions. J. Med. Chem. 2003, 46, 3021-3032. [CrossRef] [PubMed]

85. Martin, M.B.; Sanders, J.M.; Kendrick, H.; de Luca-Fradley, K.; Lewis, J.C.; Grimley, J.S.; van Brussel, E.M.; Olsen, J.R.; Meints, G.A.; Burzyńska, A.; et al. Activity of Bisphosphonates against Trypanosoma brucei rhodesiense. J. Med. Chem. 2002, 45, 2904-2914. [CrossRef] [PubMed]

86. Sanders, J.M.; Gomez, A.O.; Mao, J.; Meints, G.A.; van Brussel, E.M.; Burzyńska, A.; Kafarski, P.; Gonzalez-Pacanowska, D.; Oldfield, E. 3-D QSAR investigations of the inhibition of Leishmania major farnesyl pyrophosphate synthase by bisphosphonates. J. Med. Chem. 2003, 46, 5171-5183. [CrossRef] [PubMed]

87. Ghosh, S.; Chan, J.M.; Lea, C.R.; Meints, G.A.; Lewis, J.C.; Tovian, Z.S.; Flessner, R.M.; Loftus, T.C.; Bruchhaus, I.; Kendrick, H.; et al. Effects of bisphosphonates on the growth of Entamoeba histolytica and Plasmodium species in vitro and in vivo. J. Med. Chem. 2004, 47, 175-187. [CrossRef] [PubMed]

88. Ling, Y.; Sahota, D.; Odeh, S.; Chan, J.M.; Araujo, F.G.; Moreno, S.N.; Oldfield, E. Bisphosphonate inhibitors of Toxoplasma gondi growth: In vitro, QSAR, and in vivo investigations. J. Med. Chem. 2005, 48, 3130-3140. [CrossRef] [PubMed]

89. Tanaka, K.S.E.; Houghton, T.J.; Kang, T.; Dietrich, E.; Delorme, D.; Ferreira, S.S.; Caron, L.; Viens, F.; Arhin, S.S.; Sarmiento, I.; et al. Bisphosphonated fluoroquinolone esters as osteotropic prodrugs for the prevention of osteomyelitis. Bioorg. Med. Chem. 2008, 16, 9217-9229. [CrossRef] [PubMed]

90. Forlani, G.; Petrolino, D.; Fusetti, M.; Romanini, L.; Nocek, B.; Joachimiak, A.; Berlicki, L.; Kafarski, P. $\delta^{1}$-Pyrroline-5-carboxylate reductase as a new target for therapeutics: Inhibition of the enzyme from Streptococcus pyogenes and effects in vivo. Amino Acids 2012, 42, 2283-2291. [CrossRef] [PubMed]

91. Brel, V.K. Synthesis of gem-bisphosphonates with (3-aryl-4,5-dihydroxisoxazol-5-yl)methylamino moiety. Mendeleev Commun. 2015, 25, 234-235. [CrossRef]

92. Kosikowska, P.; Bochno, M.; Macegoniuk, K.; Forlani, G.; Kafarski, P.; Berlicki, Ł. Bisphosphonic acids as effective inhibitors of Mycobacterium tuberculosis glutamine synthetase. J. Enzyme Inhib. Med. Chem. 2016, 31, 931-938. [CrossRef] [PubMed]

93. Lacbay, C.M.; Mancuso, J.; Lin, Y.-S.; Bennett, N.; Götte, M.; Tsantrizos, Y.S. Modular assembly of purine-like bisphosphonates as inhibitors of HIV-1 reverse transcriptase. J. Med. Chem. 2014, 57, 7435-7449. [CrossRef] [PubMed] 
94. Shaddy, A.A.; Kamel, A.A.; Abdou, W.M. Synthesis, quantitative structure-activity relationship, and anti-inflammatory profiles of substituted 5- and 6-N-heterocycle bisphosphonate esters. Chem. Commun. 2013, 43, 236-252. [CrossRef]

95. Kafarski, P.; Lejczak, B.; Forlani, G. Herbicidally active aminomethylenebisphosphonic acids. Heteroat. Chem. 2000, 11, 449-453. [CrossRef]

96. Forlani, G.; Berlicki, Ł.; Duò, M.; Dziędzioła, G.; Giberti, S.; Bertazzini, M.; Kafarski, P. Synthesis and Evaluation of Effective Inhibitors of Plant $\delta^{1}$-Pyrroline-5-carboxylate Reductase. J. Agric. Food Chem. 2013, 61, 6792-6798. [CrossRef] [PubMed]

97. Giberti, S.; Bertazzini, M.; Liboni, M.; Berlicki, Ł.; Kafarski, P.; Forlani, G. Phytotoxicity of aminobisphosphonates targeting both $\delta 1$-pyrroline-5-carboxylate reductase and glutamine synthetase. Pest Manag. Sci. 2016, in press. [CrossRef] [PubMed]

98. Dobosz, A.; Spychała, J.; Ptak, T.; Chmielewska, E.; Maciejewska, G.; Kafarski, P.; Młynarz, P. Electrochemical and spectroscopic investigations of selected $\mathrm{N}$-heteroalkylaminomethylene-bisphosphonic acids with $\mathrm{Pb}$ (II) ions. Coord. Chem. Rev. 2016, in press. [CrossRef]

99. Dąbrowska, E.; Burzyńska, A.; Mucha, A.; Matczak-Jon, E.; Sawka-Dobrowolska, W.; Berlicki, Ł.; Kafarski, P. Insight into the mechanism of three component condensation leading to aminomethylenebisphosphonates. J. Organomet. Chem. 2009, 6943, 3806-3813. [CrossRef]

100. Lejczak, B.; Boduszek, B.; Kafarski, P.; Forlani, G.; Wojtasek, H.; Wieczorek, P. Mode of action of herbicidal derivatives of aminomethylenebisphosphonic acid. I. Physiologic activity and inhibition of anthocyanin biosynthesis. J. Plant Growth Regul. 1996, 15, 109-113. [CrossRef]

101. Bochno, M.; Berlicki, Ł. A three-component synthesis of aminomethylene bis- $H$-phosphinates. Tetrahedron Lett. 2014, 55, 219-223. [CrossRef]

102. Rodriguez, J.B. Tetraethyl vinylidenebisphosphonate: A versatile synthon for the preparation of bisphosphonates. Synthesis 2014, 46, 1129-1142. [CrossRef]

103. Rosso, V.S.; Szajman, S.H.; Malayil, L.; Galizzi, M.; Moreno, S.N.J.; Docampo, R.; Rodriguez, J.B. Synthesis and biological evaluation of new 2-alkylaminoethyl-1,1-bisphosphonic acids against Trypanosoma cruzi and Toxoplasma gondii targeting farnesyl diphosphate synthase. Bioorg. Med. Chem. 2011, 19, 2211-2217. [CrossRef] [PubMed]

104. Szajnman, S.H.; Liñares, G.E.G.; Li, Z.-H.; Jiang, C.; Galizzi, M.; Bontempi, E.; Ferella, M.; Moreno, S.N.J.; Docampo, R.; Rodriguez, J.B. Synthesis and biological evaluation of 2-alkylaminoethyl-1,1-bisphosphonic acids against Trypanosoma cruzi and Toxoplasma gondii targeting farnesyl diphosphate synthase. Bioorg. Med. Chem. 2008, 15, 3283-3290. [CrossRef] [PubMed]

105. Herczegh, P.; Buxton, T.B.; McPherson, J.C., III; Kovács-Kulyassa, A.; Brewer, P.D.; Sztaricskai, F.; Stroebel, G.C.; Plowman, K.M.; Farcasiu, D.; Hartmann, J.F. Osteoadsorptive bisphosphonate derivatives of fluoroquinolone antibacterials. J. Med. Chem. 2002, 45, 2338-2341. [CrossRef] [PubMed]

106. Houghton, T.J.; Tanaka, K.S.E.; Kang, T.; Dietrich, E.; Lafontaine, Y.; Delorme, D.; Ferreira, S.S.; Viens, F.; Arhin, F.F.; Sarmiento, I.; et al. Linking bisphosphonates to the free amino groups in fluoroquinolones: Preparation of osteotropic prodrugs for the prevention of osteomyelitis. J. Med. Chem. 2008, 51, 6955-6969. [CrossRef] [PubMed]

107. Dziegielewski, M.; Hejmanowska, J.; Albrecht, Ł. A convenient approach to a novel group of quaternary amino acids containing a geminal bisphosphonate moiety. Synthesis 2014, 46, 3233-3239. [CrossRef]

108. Simoni, D.; Gebbia, N.; Invidiata, M.P.; Eleopra, M.; Marchetti, P.; Rondanin, R.; Baruchello, R.; Provera, S.; Marchioro, C.; Tolomeo, M.; et al. Design, synthesis, and biological evaluation of novel aminobisphosphonates possessing an in vivo antitumor activity through a $\gamma \delta$-T lymphocytes-mediated activation mechanism. J. Med. Chem. 2008, 51, 6800-6807. [CrossRef] [PubMed]

109. Sankala, E.; Weisell, J.M.; Huhtala, T.; Närvänen, A.T.O.; Vepsäläinen, J.J. Synthesis of novel bisphosphonate polyamine conjugates and their affinity to hydroxyapatite. Arch. Org. Chem. 2012, 2012, 233-241.

110. Chen, K.M.C.; Hudock, M.P.; Zhang, Y.; Guo, R.T.; Cao, R.; No, J.H.; Liang, P.H.; Ko, T.-P.; Chang, T.H.; Chang, S.; et al. Inhibition of geranylgeranyl diphosphate synthase by bisphosphonates: A crystallographic and computational investigation. J. Med. Chem. 2008, 51, 5594-5607.

111. Zhang, Y.; Leon, A.; Song, Y.; Studer, D.; Haase, C.; Kościelski, Ł.A.; Oldfield, E. Activity of nitrogen-containing and non-nitrogen-containing bisphosphonates on tumor cell lines. J. Med. Chem. 2006, 49, 5804-5814. [CrossRef] [PubMed] 
112. Makarov, M.V.; Rybalkina, E.Y.; Röschenthaler, G.-V. New 3,5-bis(arylidene)-4-piperidones with bisphosphonate moiety: Synthesis and antitumor activity. Russ. Chem. Bull. Int. Ed. 2014, 63, 1181-1186. [CrossRef]

113. Skarpos, H.; Osipov, S.N.; Vororb'eva, D.V.; Odinets, I.L.; Lork, E.; Röschenthaler, G.-V. Synthesis of functionalized bisphosphonates via click chemistry. Org. Biomol. Chem. 2007, 5, 2361-2367. [CrossRef] [PubMed]

114. Liu, S.; Bi, W.; Li, X.; Chen, X.; Qu, N.; Zhao, Y. A Practical method to synthesize 1,2,3-triazole-aminobisphosphonate derivatives. Phosphorus Sulfur Relat. Elem. 2015, 190, 1735-1742. [CrossRef]

115. Gouault-Bironneau, S.; Deprèle, S.; Sutor, A.; Montchamp, J.-L. Radical reaction of sodium hypophosphite with terminal alkynes: Synthesis of 1,1,-bis-H-phosphinates. Org. Lett. 2005, 7, 5909-5912. [CrossRef] [PubMed]

116. Kuźnik, A.; Mazurkiewicz, R.; Grymel, M.; Zielińska, K.; Adamek, J.; Chmielewska, E.; Bochno, M.; Kubica, S. A new method for the synthesis of $\alpha$-aminoalkylidenebisphosphonates and their asymmetric phosphonyl-phosphinyl and phosphonyl-phosphinoyl analogues. Beilstein J. Org. Chem. 2015, 11, 1418-1424. [CrossRef] [PubMed]

117. Tanaka, K.S.; Dietrich, E.; Ciblat, S.; Métayer, C.; Arhin, F.F.; Sarmiento, I.; Moeck, G.; Parr, T.R., Jr.; Far, A.R. Synthesis and in vitro evaluation of bisphosphonate glycopeptide prodrugs for the treatment of osteomyelitis. Bioorg. Med. Chem. Lett. 2010, 20, 1355-1359. [CrossRef] [PubMed]

118. Bala, J.L.F.; KAshemirov, B.A.; McKenna, C.E. Synthesis of novel bisphosphonic acid alkene monomer. Synth. Commun. 2010, 40, 3577-3584. [CrossRef]

119. Lecerclé, D.; Gabillet, S.; Gomis, J.-M.; Taran, F. A facile synthesis of aminomethylene bisphosphonates through rhodium carbenoid mediated N-H insertion reaction. Application to the preparation of powerful uranyl ligands. Tetrahedron Lett. 2008, 49, 2083-2087. [CrossRef]

120. Masschelein, K.G.R.; Stevens, C.V. Double nucleophilic 1,2-addition of silylated dialkyl phosphites to 4-phosphono-1-aza-1,3-dienes: Synthesis of $\gamma$-phosphono- $\alpha$-aminobisphosphonates. J. Org. Chem. 2007, 72, 9248-9252. [CrossRef] [PubMed]

121. Rassukana, Y.V.; Davydova, K.O.; Onys'ko, P.P.; Sinitsa, A.D. Synthesis and rearrangements of $\mathrm{N}$-trichloroacetylfluoroacetimidolyl chloride and its phosphorylation products. J. Fluor. Chem. 2002, 117, 107-113. [CrossRef]

122. Rassukana, Y.V.; Onys'ko, P.P.; Davydova, K.O.; Sinitsa, A.D. A new reaction of phosphorylated $\mathrm{N}$-sulfonylimines with hydrophosphoryl agents involving C-N transfer of phosphoryl groups. Tetrahedron Lett. 2004, 45, 3899-3902. [CrossRef]

123. Kolotilo, N.V.; Sinitsa, A.D.; Rassukanaya, Y.V.; Onys'ko, P.P. N-Sulfonyl- and N-phosphorylbenzimidoylphosphonates. Russ. J. Gen. Chem. 2006, 76, 1210-1218. [CrossRef]

124. Romanenko, V.D.; Kukhar, V.P. Methylidynetrisphosphonates: Promising C1 building block for the design of phosphate mimetics. Beilstein J. Org. Chem. 2013, 9, 991-1001. [CrossRef] [PubMed]

125. Kafarski, P.; Lejczak, B. A facile conversion of aminoalkanephosphonic acids into their diethyl esters. The use of unblocked aminophosphonic acids in phosphono peptide synthesis. Synthesis 1988, 4, 307-310. [CrossRef]

126. Turhanen, P.A.; Weisell, J.; Vepsäläinen, J.J. Preparation of mixed trialkyl alkylcarbonate derivatives of etidronic acid via an unusual route. Beilstein J. Org. Chem. 2012, 8, 2019-2024. [CrossRef] [PubMed]

127. Turhanen, P.A.; Vepsäläinen, J.J. Synthesis of novel (1-alkanoyloxy-4-alkanoylaminobutylidene)-1,1bisphosphonic acid derivatives. Beilstein J. Org. Chem. 2006, 2, 2. [CrossRef] [PubMed]

128. Xu, G.; Yang, C.; Bo, L.; Wu, X.; Xie, Y. Synthesis of new potential chelating agents: Catechol-bisphosphonate conjugates for metal intoxication therapy. Heteroatom Chem. 2004, 15, 251-257. [CrossRef]

129. Agyin, J.K.; Santhamma, B.; Roy, S.S. Design, synthesis, and biological evaluation of bone-targeted proteasome inhibitors for multiple myeloma. Bioorg. Med. Chem. 2013, 23, 5455-6458. [CrossRef] [PubMed]

130. Ezra, A.; Hoffman, A.; Breuer, E.; Alferiev, A.S.; Mönkkönen, J.; El Hanany-Rozen, N.; Weiss, G.; Stepensky, D.; Gati, I.; Cohen, H.; et al. A Peptide prodrug approach for improving bisphosphonate oral absorption. J. Med. Chem. 2000, 43, 3641-3652. [CrossRef] [PubMed]

131. Sun, S.; Błażewska, K.; Kadina, A.P.; Kashemirov, B.A.; Duan, X.; Triffitt, J.T.; Dunford, J.E.; Russell, R.G.R.; Ebetino, F.H.; Roelofs, A.J.; et al. Fluorescent bisphosphonate and carboxyphosphonate probes: A versatile imaging toolkit for applications in bone biology and biomedicine. Bioconj. Chem. 2016, 27, 329-340. [CrossRef] [PubMed] 
132. Liu, J.; Jo, J.; Kawai, Y.; Aoki, I.; Tanaka, C.; Yamamoto, M.; Tabata, Y. Preparation of polymer-based multimodal imaging agent to visualize the process of bone regeneration. J. Control. Release 2012, 157, 398-405. [CrossRef] [PubMed]

133. Varghese, O.P.; Sun, W.; Hilborn, J.; Ossipov, D.A. In situ cross-linkable high molecular weight hyaluronan-bisphosphonate conjugate for localized delivery and cell-specific targeting: A hydrogel linked prodrug approach. J. Am. Chem. Soc. 2009, 131, 8781-8783. [CrossRef] [PubMed]

134. Vitha, T.; Kubiček, V.; Hermann, P.; Elst, L.V.; Muller, R.N.; Kollar, Z.I.; Wolterbeek, H.T.; Breeman, W.A.P.; Lukeš, I.; Peters, J.A. Lanthanide(III) Complexes of Bis(phosphonate) Monoamide Analogues of DOTA: Bone-Seeking Agents for Imaging and Therapy. J. Med. Chem. 2008, 51, 677-683. [CrossRef] [PubMed]

135. Shao, X.; Xu, Y.; Jiao, Y.; Zhou, C. Synthesis and characterization of an alendronate-chitosan conjugate. Appl. Mech. Mater. 2012, 140, 53-57. [CrossRef]

136. Morioka, M.; Kamizono, A.; Takikawa, H.; Mori, A.; Ueno, H.; Kadowaki, S.; Nakano, Y.; Kato, K.; Umezawa, K. Design, synthesis, and biological evaluation of novel estradiol-bisphosphonate conjugates as bone-specific estrogens. Bioorg. Med. Chem. 2010, 18, 1143-1148. [CrossRef] [PubMed]

137. Dadiboyena, S. Recent advances in the synthesis of raloxifene: A selective estrogen receptor modulator. Eur. J. Med. Chem. 2012, 51, 17-34. [CrossRef] [PubMed]

138. Palma, E.; Oliveira, B.M.; Correira, J.D.G.; Gano, L.; Maria, L.; Santos, I.C.; Santos, I. A new bisphosphonate-containing ${ }^{99 \mathrm{~m}} \mathrm{Tc}(\mathrm{I})$ tricarbonyl complex potentially useful as bone-seeking agent: Synthesis and biological evaluation. J. Biol. Inorg. Chem. 2007, 12, 667-679. [CrossRef] [PubMed]

139. Reddy, R.; Dietrich, E.; Lafontaine, Y.; Houghton, T.J.; Belanger, O.; Dubois, A.; Arhin, F.F.; Sarmiento, I.; Fadhil, I.; Laquerre, K.; et al. Bisphosphonated benzoxazinorifamycin prodrugs for the prevention and treatment of osteomyelitis. ChemMedChem 2008, 3, 1863-1868. [CrossRef] [PubMed]

140. Bekker, K.S.; Chukanov, N.V.; Grigor'ev, I.A. Synthesis of a bisphosphonate derivative of folic acid. Chem. Nat. Prod. 2013, 49, 495. [CrossRef]

141. Bekker, K.S.; Chukanov, N.V.; Popov, S.A.; Grigor'ev, I.A. New Amino-Bisphosphonate Building Blocks in the Synthesis of Bisphosphonic Derivatives Based on Lead Compounds. Phosphorus Sulfur Silicon Relat. Elem. 2015, 190, 1209-1212. [CrossRef]

142. Bekker, K.S.; Chukanov, N.V.; Popov, S.A.; Grigor'ev, I.A. Conjugates of bisphosphonates with derivatives of ursolic, betulonic, and betulinic acids. Chem. Nat. Prod. 2013, 49, 581-582. [CrossRef]

143. Wang, L.; Yang, Z.; Gao, J.; Xu, K.; Gu, H.; Zhang, B.; Zhang, X.; Xu, B. A biocompatible method of decorporation: Bisphosphonate-modified magnetite nanoparticles to remove uranyl ions from blood. J. Am. Chem. Soc. 2006, 131, 13358-13359. [CrossRef] [PubMed]

144. Bekker, K.S.; Chukanov, N.V.; Grigor'ev, I.A. Synthesis of a bis-phosphonic acid derivative of trolox, a new potential antioxidant. Chem. Nat. Prod. 2013, 49, 785-786. [CrossRef]

145. Altin, A.; Akgun, B.; Bilgici, Z.S.; Turker, S.B.; Avci, D. Synthesis, photopolymerization, and adhesive properties of hydrolytically stable phosphonic acid-containing (meth)acrylamides. J. Polym. Sci. A Polym. Chem. 2014, 52, 512-522. [CrossRef]

146. Akgun, B.; Avci, D. Synthesis and evaluations of bisphosphonate-containing monomers for dental materials. J. Polym. Sci. A Polym. Chem. 2012, 50, 4854-4863. [CrossRef]

147. Yang, X.; Akhtar, X.; Rubino, S.; Leifer, K.; Hilborn, J.; Ossipov, D. Direct "click" synthesis of hybrid bisphosphonate-Hyaluronic acid hydrogel in aqueous solution for biomineralization. Chem. Mater. 2012, 24, 1690-1697. [CrossRef]

148. Gluz, E.; Grinberg, I.; Corem-Salkmon, E.; Mizrahi, D.; Margel, S. Engineering of new crosslinked near-infrared fluorescent polyethylene glycol bisphosphonate nanoparticles for bone targeting. J. Polym. Sci. A Polym. Chem. 2013, 51, 4282-4291. [CrossRef]

149. Mukaya, H.E.; Mbianda, X.Y. Macromolecular co-conjugate of ferrocene and bisphosphonate: Synthesis, characterization and kinetic drug release study. J. Inorg. Organomet. Polym. 2015, 25, 411-418. [CrossRef]

150. Beck, J.; Gharbi, S.; Herteg-Fernea, A.; Vercheval, L.; Berbone, C.; Lassaux, P.; Zervosen, A.; Marchant-Bryanert, J. Aminophosphonic acids and aminobis(phosphonic acids) as potential inhibitors of penicillin-binding proteins. Eur. J. Org. Chem. 2009, 2009, 85-97. [CrossRef]

151. Chuiko, A.L.; Filonenko, L.P.; Borisevich, A.M.; Lozinskii, M.O. pH-Dependent isomerism of (iso)thioureidomethylenebisphosphonates. Russ. J. Gen. Chem. 2009, 79, 72-77. [CrossRef] 
152. Chuiko, A.L.; Filonenko, L.P.; Lozinskii, M.O. Reaction of thioureidomethylenebisphosphonic acids with $\alpha$-haloketones: II. Effect of $\mathrm{pH}$ on the reaction pathway. Russ. J. Gen. Chem. 2009, 79, 57-66. [CrossRef]

153. Chuiko, A.L.; Filonenko, L.P.; Lozinskii, M.O. Synthesis of ((thiazol-2-ylamino)-methylene)bisphosphonic acids. Chem. Heterocycl. Compd. 2011, 47, 1137-1140. [CrossRef]

154. Sirviö, J.A.; Hasa, T.; Ahola, J.; Liimatainen, H.; Niinimäki, J.; Hormi, O. Phosphonated nanocelluloses from sequential oxidative-reductive treatment-Physicochemical characteristics and thermal properties. Carbohydr. Polym. 2015, 133, 524-532. [CrossRef] [PubMed]

155. Bonzi, G.; Salmaso, S.; Scomparin, A.; Edar-Boock, A.; Satchi-Fainaro, R.; Caliceti, P. Novel pullulan bioconjugate for selective breast cancer bone metastases treatment. Bioconj. Chem. 2015, 26, 489-501. [CrossRef] [PubMed]

(C) 2016 by the authors; licensee MDPI, Basel, Switzerland. This article is an open access article distributed under the terms and conditions of the Creative Commons Attribution (CC-BY) license (http://creativecommons.org/licenses/by/4.0/). 